\title{
Katarzyna Gara
}

Wyższa Szkoła Europejska im. ks. Józefa Tischnera w Krakowie km.gara@gmail.com

\section{Nieznane jezuickie programy teatralne w bibliotekach wileńskich ${ }^{1}$}

\section{Abstract \\ Unknown Jesuit Theatre Programmes in Vilnian Libraries}

The aim of this paper is to present eleven to date unknown Jesuit theatre programmes, summary records of dramas performed in colleges in the Polish-Lithuanian Commonwealth in the $17^{\text {th }}$ and $18^{\text {th }}$ centuries: [Antiprologue], Artaban (1757), Cineres ad iustam vindictam animati (1702), Conviva bonae mentis (1700), Corona civica, Corona religionis orthodoxae (1682), Daumondus (1690), Divina iustitia scelerum vindex (1718), Exaltatio de portis mortis (1738), Flocillus (1757), Gaudia post luctus (1680). The programmes were discovered in the following Vilnian libraries: the Vilnius University Library, the Martynas Mažvydas National Library of Lithuania, and the Wróblewski Library of the Lithuanian Academy of Sciences. The analysis is based on a programme study model applied in Dramat staropolski (Wrocław, 1976). In terms of content, the programmes recapitulate plays with motives already known from the bibliography, as well as feature new themes referring to the ancient history and the history of Polish and Lithuanian territories. The pa-

1 Niniejszy artykuł powstał w ramach projektu naukowego Kształcenie obywatela na scenach jezuickich $w$ Rzeczypospolitej Obojga Narodów. Programy teatral$n e w$ archiwach wileńskich i rzymskich SJ oraz $w$ wybranych bibliotekach polskich, finansowanego przez Narodowe Centrum Nauki pod numerem UMO-2014/13/B/ HS2/00524. Kierownikiem projektu jest prof. dr hab. Jan Okoń. 
per presents individual characteristics of each of the eleven programmes. The study supplements the research concerning old-Polish theatre and shall facilitate further analyses of source materials.

Key words: theatre programmes, Jesuit drama, the Polish-Lithuanian Commonwealth

Przedmiotem tego artykułu jest publikacja opracowania nieznanych dotychczas programów teatralnych, odnalezionych w wileńskich bibliotekach, a dokładnie rzecz ujmując, drukowanych jezuickich programów teatralnych z XVII i XVIII wieku. Celem nie jest jednak przedstawienie wnikliwej charakterystyki każdego programu z osobna, co przekroczyłoby z pewnością ramy niniejszego artykułu, ale opracowanie materiału źródłowego zgodnie z modelem wypracowanym w polskiej literaturze naukowej dotyczącej teatru staropolskiego, o czym będzie mowa niżej.

Program teatralny, zgodnie z definicją Jana Okonia ${ }^{2}$, był dokumentem w formie pisanej lub drukowanej odnoszącym się do jednostkowego widowiska teatralnego. Zawierał informacje dotyczące miejsca, czasu i okoliczności wystawienia; wymieniał wykonawców spektaklu, przedmiot i środki. Powstawał z myślą o widzach, w celu przekazania im treści rzeczowych lub również ideowych. Jak podkreśla Władysław Korotaj ${ }^{3}$, program związany był nie tyle z tekstem sztuki, ile z jej przedstawieniem, stąd miał charakter teatrologiczny, nie dramaturgiczny. Początki programów teatralnych sięgają drugiej połowy XVI wieku, ich geneza związana jest z dwiema ważnymi funkcjami - przekazaniem informacji o sztuce i jej treści oraz

2 J. Okoń, Dramat i teatr szkolny. Sceny jezuickie XVII wieku, Wrocław 1970, s. 70 (poniżej w opracowaniu programów jako Okoń).

3 W. Korotaj, Z problematyki staropolskich programów teatralnych, w: Wrocławskie spotkanie teatralne, red. W. Roszkowska, Wrocław 1967, s. 88. 
o przedstawieniu ${ }^{4}$. Opracowania podają, że pierwszy znany program teatralny ogłoszono drukiem w Billom w 1559 roku ${ }^{5}$ z kolei w Polsce pod koniec XVII wieku zaczęto tłoczyć szczegółowe programy. ${ }^{6}$. Najwcześniejsze drukowane programy sztuk wystawionych w kolegiach jezuickich polskich i litewskich, pochodzące z początku XVII wieku, zawierają takie elementy, jak: tytuł, argument, spis osób dramatu, prolog, streszczenie scen, epilog, drzeworyt herbu osoby, której dedykowano występ, oraz wiersz na herb ${ }^{7}$. W późniejszych programach często pojawia się również dedykacja i czasem spis aktorów. Do rzadkich elementów zaliczyć należy informację o miejscu akcji czy didaskalia. W miarę rozwoju dramatu jezuickiego w Rzeczypospolitej Obojga Narodów można zaobserwować również w programach rekapitulację nowych części, na przykład antyprologů Szczęśliwie zachował się krótki opis poszczególnych części programu pochodzący z końca XVII wieku, autorstwa Łukasza Ligockiego, dający dowód na to, że komponowanie programów teatralnych było przedmiotem wykładu w kolegiach jezuickich?

Szkolny teatr jezuicki Rzeczypospolitej Obojga Narodów rozwijał się intensywnie mimo zasad ogłaszanych przez władze zakonu. Jeszcze przed powstaniem ostatecznej wersji Ratio studiorum w 1599 roku pojawiła się reguła cenzury tekstów przeznaczonych do publicznych występó $\mathrm{w}^{10}$. Dokumenty rękopiśmienne dotyczące prowin-

4 J. Okoń, Dramat i teatr szkolny..., s. 12.

5 Zob. J. Poplatek, Studia z dziejów jezuickiego teatru szkolnego w Polsce, Wrocław 1957, s. 152; J. Okoń, Dramat i teatr szkolny..., s. 15.

6 Zob. J. Poplatek, Studia z dziejów jezuickiego teatru..., s. 40. Nie należy zapominać o istnieniu rękopiśmiennych sztuk i programów, por. J. Poplatek, Studia $z$ dziejów jezuickiego teatru..., s. 41-42; J. Okoń, Dramat $i$ teatr szkolny..., s. 71-74.

7 Por. J. Okoń, Dramat i teatr szkolny..., s. 16-18. Chodzi o dwa programy: Summarium tragoediae Eustachianae (1616) i Epitome comoediae Henricanae (1617).

8 Szerzej omawia budowę programu W. Korotaj, Z problematyki..., s. 93-107.

9 Opis zawarty w rękopisie Biblioteki PAN w Krakowie, sygn. 557, k. 34v. (podaję za: W. Korotaj, Z problematyki..., s. 94, gdzie można znaleźć ten fragment również w oryginalnej wersji łacińskiej na s. 94-95).

10 Zob. J. Poplatek, Studia z dziejów jezuickiego teatru..., s. 24-25. 
cji polskiej mówią o ograniczeniu przedstawień do jednego w roku, by nie odciągać uczniów od nauki ${ }^{11}$. Jak sugerują badacze, w porównaniu z dialogami trudniej o nadzór nad komediami i tragediami, w których mogą zaistnieć „treści uboczne, niewłaściwe, powstaje niebezpieczny margines, którego cenzura może nie zauważyć"12. Stąd Ratio studiorum wyraźnie zaleca: „Treść tragedii i komedii, które powinny być wystawiane w języku łacińskim i jak najrzadziej, niech będzie pobożna. Nie należy wtrącać do akcji niczego, co nie jest stosowne i nie dotyczy łaciny. Nie należy wprowadzać ani ról ani kostiumów kobiecych"13. Przepisy jednak były przez jezuitów w Polsce naginane i pod nazwą dialogów, które można było wystawiać częściej niż sztuki, kryły się w istocie tragedie i komedie ${ }^{14}$. Również w prowincji litewskiej ugruntowała się tradycja częstych przedstawień z bogatą oprawą sceniczną ${ }^{15}$.

Jeśli chodzi o okazje wystawień, Jan Poplatek wyróżnia przedstawienia stałe i nadzwyczajne ${ }^{16}$. Do stałych należały spektakle na początek i zakończenie roku szkolnego. Obchodzono również rozpoczęcie

11 Zob. Acta in prima Congregatione Provinciali Poloniae anno 1576 in Boszevia celebratae, przytoczone przez Poplatka, Studia z dziejów jezuickiego teatru..., s. 50. Zob. również I. Kadulska, Teatr jezuicki XVIII i XIX wieku w Polsce. Z antologia dramatu, Gdańsk 1997; S. Załęski, Jezuici w Polsce, t. 1-5, Lwów-Kraków 19011906.

12 W. Roszkowska, Uwagi o programowości teatru barokowego w Polsce, w: Wrocławskie spotkanie teatralne, s. 63.

${ }^{13}$ Ratio atque institutio studiorum czyli ustawa szkolna Towarzystwa Jezusowego, wstęp i oprac. K. Bartnicka, T. Bieńkowski, Warszawa 2000, s. 45. Szerzej o regułach odnoszących się do szkolnego teatru jezuickiego, a zwłaszcza prowincji polskiej i litewskiej, zob. J. Poplatek, Studia z dziejów jezuickiego teatru..., s. 9-40, 43-97.

14 Zob. J. Poplatek, Studia z dziejów jezuickiego teatru..., s. 26.

15 Zob. ibidem, s. 27. O teatrze jezuickim prowincji litewskiej zob. L. Piechnik, Dzieje Akademii Wileńskiej, t. 1-4, Rzym 1983-1990; E. Ulčinaitė, Lietuvos jėzuitu teatras. XVI-XVIII amžiaus dramu rinktine, Vilnius 2008; V. Zaborskaitè, Prie Lietuvos teatro ištakų. XVI-XVIII a. mokyklinis teatras, Vilnius 1981. Szeroko sztukę demonstratywną omawia J. Niedźwiedź, Kultura literacka Wilna (1323-1655). Retoryczna organizacja miasta, Kraków 2012 (rozdział ósmy).

16 Zob. J. Poplatek, Studia z dziejów jezuickiego teatru..., s. 36-39. 
semestru letniego po Wielkanocy. Zachowało się wiele programów dokumentujących sztuki grywane na zapusty. Uroczystości Wielkiego Tygodnia, Bożego Ciała czy Bożego Narodzenia były kolejną sposobnością do występów scenicznych ${ }^{17}$. Nie brakowało przedstawień na uroczystości świętych, a zwłaszcza patronów zakonu. Obok tego urządzano występy okolicznościowe - okazją mógł być przyjazd znamienitego gościa, mecenasa kolegium, ślub czy zgon fundatora, obrady sądów trybunalskich.

Wśród ogromnej spuścizny piśmiennictwa jezuickiego programy teatralne stanowią materiał wciąż wymagający wielopłaszczyznowych badań na dużą skalę. Wymieniając najważniejsze opracowania dotyczące twórczości dramatycznej jezuitów, należy wspomnieć przede wszystkim o pierwszej części drugiego tomu pracy Dramat staropolski od początków do powstania sceny narodowej $j^{18}$, porząadkującej i opracowującej programy odnalezione w bibliotekach polskich i wileńskich. Jest to dzisiaj wciąż podstawowa i niezbędna publikacja dla badacza teatru jezuickiego. Ponadto ważnymi pozycjami są trzy opracowania Władimira Riezanowa: $K$ istorii russkoj dramy. Èkskurs $v$ oblast' teatra iezuitov ${ }^{19}$, Iz istorii russkoj dramy. Škol'nye dejstva XVII-XVIII vv. i teatr iezuitov ${ }^{20}$ oraz Školnye dramy pol sko-litovskih iezuitskih kollegij ${ }^{21}$, zawierające omówienie programów sztuk wysta-

17 Ale w 1683 roku prowincjał Jan Berent zakazał w prowincji litewskiej wszystkich występów scenicznych w Wielki Piątek, por. ibidem, s. 38.

18 Dramat staropolski od początków do powstania sceny narodowej. Bibliografia, t. 2: Programy drukiem wydane do r. 1765, cz. 1: Programy teatru jezuickiego, oprac. W. Korotaj, J. Szwedowska, M. Szymańska, Wrocław 1976 (poniżej w opracowaniu programów jako DS II 1).

19 V.I. Rezanov, K istorii russkoj dramy. Èkskurs v oblast' teatra iezuitov, Nežin 1910 (В.И. Резанов, К истории русской драмы. Экскурс в область театра иезуитов, Нежин 1910).

20 V.I. Rezanov, Iz istorii russkoj dramy. Škol'nye dejstva XVII-XVIII vv. i teatr iezuitov, Moskva 1910 (В.И. Резанов, Из истории русской драмы. Школьные действа XVII-XVIII вв. и театр иезуитов, Москва 1910).

${ }_{21}$ V.I. Rezanov, Škol’nye dramy pol'sko-litovskih iezuitskih kollegij, Nežin 1916 (В.И. Резанов, Школьные драмы польско-литовских иезуитских коллегий, Нежин 1916). 
wionych w kolegiach polskich i litewskich, a także podające tytuły wielu zaginionych. Za pomocne i nietracące na wartości uchodzi dzieło historyka teatru i bibliografa Ludwika Simona Dykcjonarz teatrów polskich czynnych od czasów najdawniejszych do roku $1863^{22}$ oraz Carlosa Sommervogela Bibliothèque de la Compagnie de Jésus ${ }^{23}$. Wreszcie należy wspomnieć o pionierskiej i podstawowej monografii o teatrze jezuickim Jana Okonia, Dramat i teatr szkolny. Sceny jezuickie XVII wieku².

Bibliografia Dramat staropolski podaje 770 tytułów przedstawień teatralnych, a szacunkowe obliczenia badaczy mówią o kilku tysiącach przedstawień w kolegiach jezuickich Rzeczypospolitej Obojga Narodów w samym XVII wieku ${ }^{25}$. Liczby te dają wyobrażenie, na jak wielką skalę jezuici byli aktywni na polu dramatycznym i jak ważną rolę odgrywał teatr w życiu kolegiów. Ta twórczość teatralna, której piśmiennicze i drukowane świadectwa są rozproszone po wielu polskich i zagranicznych bibliotekach, stała się dziś bardziej przystępna dzięki wyżej wspomnianym opracowaniom. Z jednej strony dalsze studia nad programami teatralnymi utrudnia sama forma materiału źródłowego. Programy są bowiem drukami o niewielkiej objętości, wahającej się od jednej karty zadrukowanej tekstem $\mathrm{z}$ obu stron do kilku lub kilkunastu kart. Taka objętość mogła być niejednokrotnie przyczyną zwykłej utraty czy zaginięcia druku wśród setek tysięcy woluminów biblioteki. Ponadto przebadane dotychczas programy w wielu przypadkach okazują się egzemplarzami w znacznym stopniu zniszczonymi, z brakującymi kartami lub naddartymi krawędziami. Nierzadko zdarzają się druki wręcz złożone wpół, przetarte, mocno zabrudzone czy ze śladami zamoczenia, uniemożliwiającymi lekturę. Poza tym badacz musi się zmierzyć z faktem, że materiał

22 L. Simon, Dykcjonarz teatrów polskich czynnych od czasów najdawniejszych do roku 1863, Warszawa 1935.

23 C. Sommervogel, A. de Backer, A. de Backer, A. Carayon, Bibliothèque de la Compagnie de Jésus, t. 1-12, Bruxelles-Paris 1890-1960.

24 J. Okoń, Dramat i teatr szkolny...

25 Zob. ibidem, s. 70-79. 
źródłowy jest rozproszony po wielu zbiorach bibliotecznych, jak pokazują egzemplarze z podaną lokalizacją, wynotowane w Dramacie staropolskim. Z drugiej strony świadomość liczby zaginionych programów - ich tytuły zostały bowiem wymienione w bibliografiach otwiera sposobność ponownej kwerendy i przeszukiwania zasobów bibliotecznych z szansą na odnalezienie zagubionych druków.

Niniejszy artykuł jest owocem kwerendy przeprowadzonej w bibliotekach wileńskich, w wyniku której zostały odkryte nowe drukowane jezuickie programy teatralne, dotychczas nieznane z opracowań naukowych ${ }^{26}$. Badania odbyły się w trzech bibliotekach: w Bibliotece Uniwersyteckiej, w Litewskiej Bibliotece Narodowej im. Martynasa Mazvydasa oraz w Bibliotece Wróblewskich. W wyniku poszukiwań udało się odnaleźć jedenaście programów sztuk wystawionych przez jezuitów w XVII i XVIII wieku w Wilnie, Warszawie, Kownie i Poznaniu (dwa programy nie podają miejsca wystawienia). Celem tego artykułu jest opracowanie owych programów i udostępnienie ich do dalszych badań. Najwcześniejszy datowany program to Corona religionis orthodoxae, pochodzący z 1682 roku, najpóźniejszy - Flocillus, przedstawiający treść tragedii wystawionej 1 sierpnia 1757 roku, którą poprzedza sztuka Artaban, wystawiona również w Wilnie pod koniec lipca tego samego roku. Zaprezentowane poniżej programy ukazują różnorodne treści: wątki z historii starożytnej, na przykład Antyprolog, legendarne dzieje Polski - Cineres ad iustam vindictam animati - czy tematy japońskie, jak w programie Gaudia post luctus, nawiązujące do znanych z Dramatu staropolskiego programów, i cał-

26 Równie ciekawy wydaje się nieznany dotychczas rękopiśmienny osiemnastowieczny program Facundus pro veritate Tullius B. Ioannes Cantius autorstwa Jerzego Wolskiego, doklejony do drukowanego programu Facilis descensus averni in Vitaldo [...] sua sponte Daemonis mancipe [...] (Lwów 1719) o sygnaturze IV 31174 przechowywanego w dziale starych druków Biblioteki Uniwersyteckiej w Wilnie. Wzmianki wymaga także rękopis o sygnaturze F 3-1118 (dział rękopisów Biblioteki Uniwersyteckiej w Wilnie) zawierający tekst sztuki Morus Angliae Cancellarius tragedia, wystawionej w lwowskim kolegium w 1765 roku. Oba teksty są obecnie przedmiotem badań. 
kiem nowe, których opracowanie przyczyni się w pewnym stopniu do badań nad szkolnym teatrem jezuickim Rzeczypospolitej Obojga Narodów. Podane w programach daty oraz opisy słowne informują o następujących okazjach wystawień: zakończenie roku szkolnego (Artaban, Divina iustitia scelerum vindex, Flocillus), zapusty (Cineres ad iustam vindictam animati, Conviva bonae mentis, Exaltatio de portis mortis), konsekracja biskupia (Corona religionis orthodoxae) i uroczystości Wielkiego Tygodnia (Gaudia post luctus).

\section{Zasady opracowania materiału źródłowego}

Celem przejrzystości postanowiono przyjąć tu model wypracowany przez zespół Pracowni Bibliografii Staropolskiej i Historii Książki IBL PAN zastosowany w Dramacie staropolskim. Ze względu na to, że dwa $\mathrm{z}$ poniższych programów nie podają roku wydania ani miejsca wystawienia, dla jasności zrezygnowano z porządku chronologicznego oraz podziału według miejsca wystawienia, jak przyjęto w Dramacie staropolskim, i ułożono programy w kolejności alfabetycznej. Opis zatem zawiera następujące kategorie: tytuł skrócony, liczbę kart, odpis karty tytułowej, język, gatunek, podział dramatu na części, osoby, miejsce akcji, wstawki choreograficzne, muzyczne i wokalne, inscenizacja, źródło, treść, uwagi dotyczące autorstwa i odniesienia bibliograficzne. W tytule skróconym podano w nawiasie kwadratowym autorstwo na podstawie rękopiśmiennej notatki. Ponadto tytuł skrócony zawiera adres wydawniczy, datę wystawienia i format. Jeśli karta tytułowa nie informuje o dacie i miejscu wydania, zaznaczono to w nawiasie kwadratowym (br. m. dr.) i podano sugestię co do tego aspektu. W przypadku programu Conviva bonae mentis pod tytułem skróconym znajduje się informacja o wzmiance w Bibliografii Estreichera (podano numer tomu i stronę). Poniżej zamieszczono zestawienie sygnatur składek arkuszowych. Następnie przedstawiono wierny odpis karty tytułowej bez podziału na wiersze i podania kroju pisma. Długie „s” (f) jest w odpisie zastąpione zwykłym „s”. 
Zaznaczono obecność ozdobników drukarskich. W punkcie "Język" znajduje się informacja o języku programu, a nie tekstu sztuki, której stanowił streszczenie. Gatunek został określony na podstawie tytułu lub zaproponowany na podstawie analizy programu. W kategorii „Podział” opisano strukturę sztuki zgodnie z programem. Następnie umieszczone zostały uwagi dotyczące elementów choreograficznych, muzycznych i wokalnych. Poniżej podano osoby - postacie dramatu $-\mathrm{z}$ zaznaczeniem, czy wykaz znajduje się w programie. W przypadku programów dwujęzycznych przyjęto wersję łacińską. Wypisano również nazwiska aktorów, jeśli program zawierał taki spis. Punkt „Inscenizacja” podaje uwagi dotyczące przedstawienia i scenografii sporządzone na podstawie analizy programu. Jeśli program podawał źródło sztuki, stanowiło to kolejny punkt opisu. Poniżej zamieszczono treść przedstawienia, którą starano się odtworzyć jak najwierniej, opierając się na sumariuszu. Przedostatnim punktem opracowania są uwagi dotyczące autorstwa i odniesienia bibliograficzne. Opracowanie zamyka podanie lokalizacji egzemplarza wraz z sygnaturą.

\section{Programy teatralne}

\section{1.}

[Antyprolog?] 2 ${ }^{\circ}$.

K. nlb. 4, sygn. $\mathrm{B}-\mathrm{C}_{2}$ (brak karty A-A $\mathrm{A}_{2}$.

[brak karty tytułowej].

K. $B_{1}$ r. $-C_{1}$ r.: tekst. $C_{1}$ v. $-C_{2}$ v.: spis osób.

Język: polski.

Gatunek: tragedia.

Podział: Antyprolog. Prolog. Krotofilny widok. Akt I sc. 1-6. Chór I. Krotofilny widok. Akt II sc. 1-6. Chór II. Krotofilny widok. Akt III sc. 1-6. Epilog.

Akt I sc. 3: perski salt, „powabne kanty”. Akt III sc. 3: „różne salty”. 
Osoby (brak spisu): Merkuriusz; Apollo; Pallas; cesarz Trajan; Placyd-Eustachius, hetman rzymskich wojsk; Fama; Persowie, Indowie; Teopista, przyjaciel Placyda; Agapius, Teopistus, dwaj synowie Placyda; sługi Placyda; Jan, katolicki Kapłan; Smutek; Niestateczność; Rozpacz; Stateczność; Roztropność; Miłość Boska; Honor; Państwa Rzymskiego Geniusz; „Pan okrętu”; oracze; pasterze; Kmieć; rotmistrzowie Achacius i Antiochus; żołnierze; cesarz Adrian; rycerstwo.

Aktorzy grający wymienione role („Osoby do aktu należące”): z Filozofii: Jędrzej z Saka Piętkiewicz; Jerzy z Kuropków Czerniewski; Jan z Biedziun Bieduński; Ignacy Łada Łazowski; Marek Narutowicz; Michał Makarewicz; Mateusz Kalinowski. Z Retoryki: Krzysztof z Towiłła Bolcewicz, koniuszyc powiatu wiłkomirskiego; Ignacy Rynwid Mickiewicz, cześnikowicz halicki; Michał Rynwid Mickiewicz, cześnikowicz halicki; Ignacy Sawiński, cześnikowicz inflancki; Marcin z Powodajów Jackiewicz; Franciszek Goliszański; Tadeusz Janczewski; Antoni Szymanowski; Krzysztof Zakrzewski; Franciszek Juszkiewicz. Z Poetyki: Jan Poklewski Koziełł, skarbnikowicz powiatu lidzkiego; Daniel Talat Kiełłpsz, cześnikowicz powiatu wiłkomirskiego; Michał Szorc, skarbnikowicz ziemi bielskiej; Ignacy Szwykowski, podstolic smoleński; Kazimierz Syrwid, strażnikowicz słonimski; Tadeusz Ostroga Kulesza, strażnikowicz orszański; Józef Kościesza Żaba, skarbnikowicz połocki; Tadeusz z Lichadziejewa Gliński, cześnikowicz łęczycki; Onufry Lenkiewicz, horodniczyc parnawski; Józef Szarski; Tadeusz z Kuropków Czerniewski; Ignacy Szeryn, porucznikowicz J.K.M. Z Syntaktyki: Ludwik Kuprol Piętkiewicz, łowczyc powiatu wiłkomirskiego; Józef Bibersztein Charmański, Oboźnic województwa trockiego; Stanisław Talat Kiełłpsz, cześnikowicz wiłkomirski; Jędrzej Junosza Malicki, stolnikowicz smoleński; Józef Julewicz Podernia, mostowniczyc witebski; Maciej Junosza Malicki, stolnikowicz smoleński; Józef Chojecki, starościc rudnicki; Tadeusz z Zulów Gintowtt, podczaszyc wiłkomirski; Adam Lenkiewicz, horodniczyc parnawski; Paweł Szczuka; Józef Kongied Skurewicz; Piotr Areymowicz. Z Gramatyki: Ignacy z Towiłła Bolcewicz, koniuszyc powiatu wiłkomirskiego; Tadeusz Szorc, łowczyc 
ziemi bielskiej; Jędrzej Bielski, wojskowicz województwa brzeskiego; Tadeusz z Duninów Ślepść; Ignacy Syrwid, strażnikowicz słonimski; Michał Zegzdra; Kazimierz Koziełł; Józef Golthott Uliński; Adam Gintowtt Łokiański; Kazimierz Arcymowicz. Z Infimy: Ksawery Bohusz, kluczny województwa wileńskiego; Stanisław Rudnicki Sipayło, cześnikowicz orszański; Jan z Junków Sokołowski, starościc strubiski; Stanisław Wardomski Bronic, podczaszyc województwa wileńskiego; A. Damian Ornofla Giedroyć, podstolic kowieński; Kazimierz Wardomski Bronic, podczaszyc województwa wileńskiego; Jakub Petrusewicz, regentowicz województwa wileńskiego; Hieronim Szwykowski, podstolic smoleński; Dionizy Bielski, wojskowicz województwa brzeskiego; Józef Syrwid, strażnikowicz słonimski; Hilary Woydag, koniuszyc lidzki; Kazimierz Bielski, wojskowicz brzeski; Bartłomiej Grothuz, chorążyc J.K.M.; Kazimierz Alexandrowicz, skarbnikowicz mścisławski; Jan Kościesza Żaba, skarbnikowicz połocki; Simon Lenkiewicz, horodniczyc parnawski; Bogdan Gierlad Towiański, strażnikowicz wiłkomirski; Jerzy z Kordatów Makarski, podstolic smoleński; Józef Bereśniewicz, miecznikowicz upitawski; Tadeusz z Rymka Dawksza, komornikowicz wiłkomirski; Stanisław Platt, chorążyc J.K.M.; Antoni Woyzwiłło, cześnikowicz bracki; Jędrzej Łoyba; Jędrzej Towgin; Józef Okmiański; Franciszek Ewert; Franciszek Gaylewicz; Daniel Iwaszkiewicz; Jan Iwaszkiewicz; Michał Romanowski.

„Inne zaś Osoby do Scen należące na Teatrum prezentować się będą”.

Inscenizacja: Akt I sc. 1: Trajan ogłasza Placyda hetmanem wojsk rzymskiej armii; sc. 2: Placyd wzywa bogów, wyrusza z wojskiem; Persowie jednoczą siły z Indami, Placyd zwycięża Persów i Indów; sc. 3: triumf Placyda w Rzymie, uczta; sc. 4: łowy, jeleń z krzyżem i wizerunkiem Jezusa, wieszczy głos; sc. 5: Placyd udaje się do katolickiego kapłana. Akt II sc. 2: walka Stateczności, Roztropności i Miłości Boskiej z Niestatecznością i Rozpaczą; sc. 3: Placyd-Eustachius z przyjacielem i synami udaje się do Egiptu; sc. 6: wilk i lew porywają synów Placyda-Eustachiusa, oracze i pasterze ratują chłopców; Placyd-Eustachius u kmiecia we wsi Badyzus. Akt III sc. 1: Trajan roz- 
kazuje szukać Placyda; sc. 2: rotmistrzowie Trajana we wsi Badyzus; sc. 3: Placyd-Eustachius przybywa do Rzymu, uczta; sc. 4: Placyd-Eustachius pokonuje nieprzyjacielskie wojska; sc. 5: Placyd-Eustachius przybywa do Rzymu, nowy cesarz Adrian go wita; Placyd-Eustachius z synami i przyjacielem za wiarę chrześcijańską rzuceni lwom na pożarcie, lwy się korzą; sc. 6: Placyd-Eustachius z synami i przyjacielem giną spaleni w miedzianym wole.

Treść: W Antyprologu Merkury, Apollo i Pallada chwalą podkomorzego pińskiego. - Prolog: „Szczęście, Fortuna odmienna, błądzi // Trwa bez odmiany, to co Bóg sądzi”. - Cesarz Trajan ogłasza Placyda Hetmanem wojsk rzymskich. Placyd pokonuje Persów i Indów, wkracza triumfalnie do Rzymu, Trajan wyprawia ucztę na jego cześć. Placyd udaje się na polowanie, ściga jelenia $\mathrm{z}$ wizerunkiem krzyża i Jezusa między rogami, słyszy głos Chrystusa, poddaje się jego woli. Opowiada o tym zdarzeniu przyjacielowi, który radzi, by słuchać poleceń Chrystusa. Placyd udaje się z przyjacielem i synami do katolickiego kapłana Jana, który wpisuje ich „w regestr wiernych Chrystusowych”. Przyjaciel przybiera imię Teopista, starszy syn Agapius, młodszy Teopistus, Placyd - Eustachius. Placyd-Eustachius wraca na miejsce objawienia i modli się, przyrzeka wytrwałość w cierpieniach, które go czekają w przyszłości. Dowiadując się o nieszczęściach swojej rodziny, prosi Jezusa o silną wolę. Stateczność, Roztropność i Miłość Boska wtrącają do piekła Niestateczność i Rozpacz. Placyd-Eustachius skrycie udaje się z synami i przyjacielem do Egiptu, Honor i Geniusz państwa rzymskiego ubolewają z tego powodu. Kapitan okrętu jako zapłatę za przewóz przemocą odbiera Placydowi-Eustachiusowi przyjaciela. Placyd-Eustachius udaje się w swoją drogę, tymczasem kapitan okrętu nagle umiera i przyjaciel zostaje ocalony. Kiedy Placyd-Eustachius przeprawia się przez rzekę, jednego jego syna porywa lew, drugiego wilk, ale oracze i pasterze ich ratują. Nieświadom tego Placyd-Eustachius pogrążony w smutku udaje się do wsi Badyzus i w zamian za pracę u kmiecia otrzymuje wyżywienie. Kiedy Fama donosi Trajanowi o zagrożeniu i zbliżającej się wojnie, cesarz wysyła na poszukiwania Placyda rot- 
mistrzów, którzy odnajdują go we wsi Badyzus, i po 15 latach Placyd-Eustachius wraca do Rzymu. Trajan wyprawia ucztę na cześć „Hetmana”. Placyd-Eustachius ogłasza pobór do wojska, dostrzega dwóch młodzieńców odznaczających się męstwem - będących w istocie jego synami - i zaprasza ich codziennie do stołu hetmańskiego. Po wygranej bitwie bracia się rozpoznają, Teopista rozpoznaje swego przyjaciela Placyda-Eustachiusa, ten swoich synów. Wojsko wraca do Rzymu, Fama donosi Placydowi-Eustachiusowi o śmierci Trajana. Nowy cesarz Adrian przyjmuje Hetmana ze czcią i zamierza dziękować bożkom za zwycięstwo. Placyd-Eustachius wyznaje, że jest chrześcijaninem, Adrian wtrąca go do więzienia razem $\mathrm{z}$ synami i przyjacielem i skazuje na śmierć przez pożarcie przez lwy. „Lwy się korzą i nogi ich liżą". Więźniowie stają przed cesarzem, Adrian po rozmowie $\mathrm{z}$ nimi ponownie skazuje ich na śmierć przez spalenie $\mathrm{w}$ miedzianym wole. Placyd-Eustachius $\mathrm{z}$ synami i przyjacielem $\mathrm{z}$ radością poddają się wyrokowi. - Epilog: „Ten wizerunek człowiecze niech twym zdaniem rządzi // A z traktu zbawiennego dusza twa nie zbłądzi”. - Chór I: „Gardzić tym trzeba // Co nieda Nieba”. Chór II: „Kto się sercem w Niebo wzbija // Ten tym gardzi co przemija”.

Uwagi: Sztuka została wystawiona prawdopodobnie około połowy XVIII wieku, wskazują na to nazwiska uczniów. Ostatnia strona, jak również oprawy opatrzone są notatkami, w których pojawiają się daty 1771 i 1772 . Por. DS II 1, nr 308, 379 i 509; por. Okoń, Dramat i teatr szkolny, s. 16, 18, 31, 39, 115-116, 118, 155, 162-163, 167, 173, 240, 252, 335, 378, 385.

Egzemplarze: Biblioteka Uniwersytecka w Wilnie, IV 24642 (w katalogu kartkowym figuruje pod hasłem "Antyprologus”, w dziale XVIII w.). 


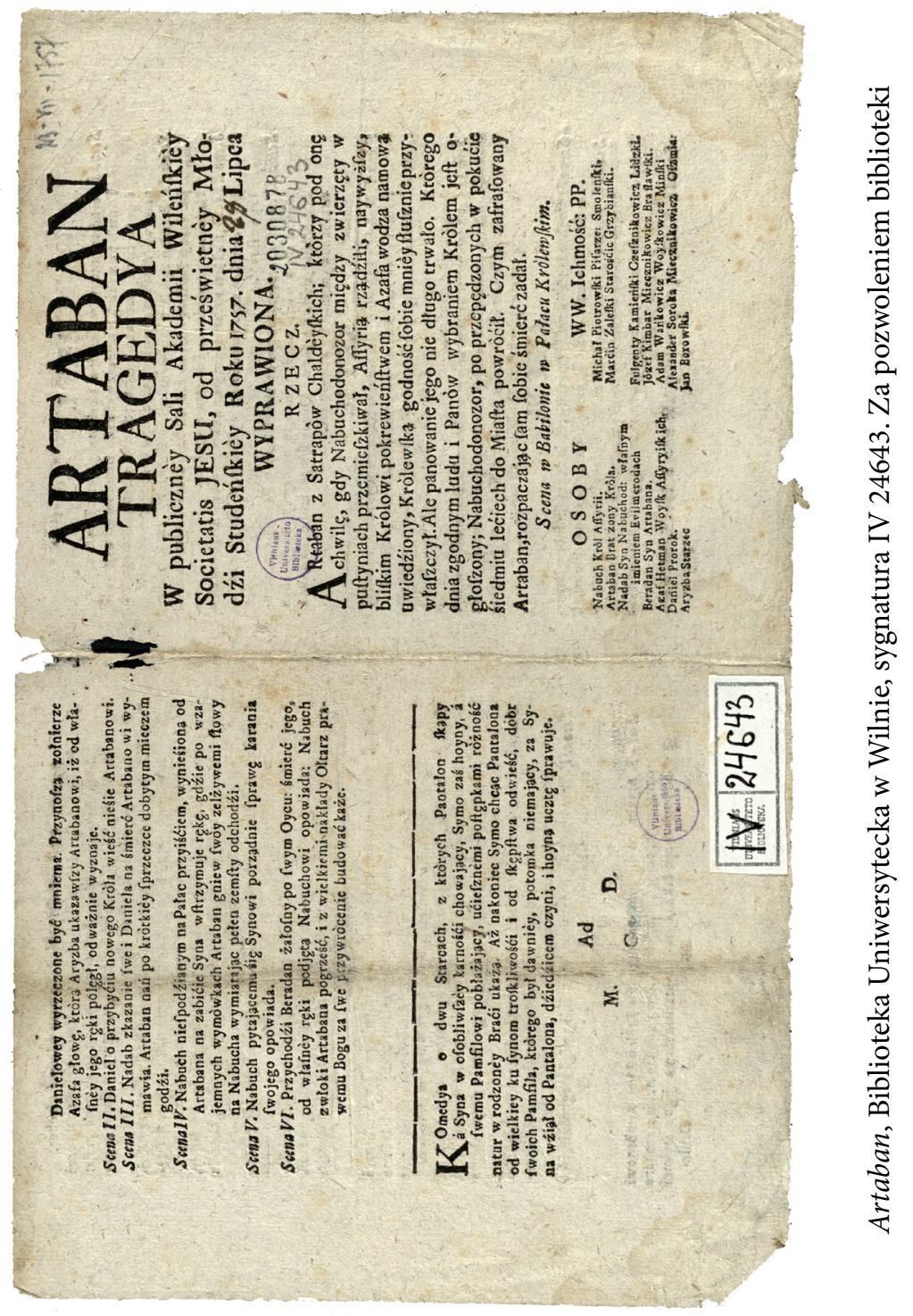




\section{2.}

Artaban tragedia, w publicznej sali Akademii Wileńskiej Societatis Jesu, od prześwietnej młodzi studenckiej roku 1757 dnia [28] lipca. [br. m. dr., Wilno?, Druk Akad. S.I.?, przed 28 VII 1757]. $4^{\circ}$.

K. nlb. 2, sygn. $A_{2}$.

[Tytuł nagłówkowy]: ARTABAN TRAGEDYA W publiczney Sali Akademii Wileńskiey Societatis JESU, od prześwietney Młodźi Studeńskiey Roku 1757 dnia [dopisano: 28] Lipca WYPRAWIONA.

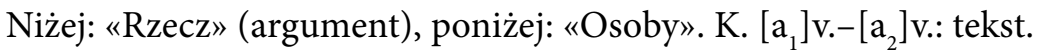

Język: polski.

Gatunek: tragedia.

Podzial: Akt I sc. 1-4. Akt II sc. 1-4. Akt III sc. 1-8. Akt IV sc. 1-4. Akt V sc. 1-6.

Osoby: Nabuch, król Assyrii - Michał Piotrowski, pisarzewic smoleński; Artaban, brat żony króla - Marcin Zaleski, starościc grzybiański; Nadab, syn Nabuchodonozora, własnym imieniem Evilmerodach - Fulgenty Kamieński, czesznikowicz lidzki; Beradan, syn Artabana - Józef Kimbar, miecznikowicz brasławski; Azaf, hetman wojsk asyryjskich - Adam Wańkowicz, wojskowicz miński; Daniel, prorok - Alexander Soroka, miecznikowicz oszmiański; Aryzba, starzec - Jan Borowski.

Miejsce akcji: Babilon, pałac królewski.

Inscenizacja: Akt I sc. 1: Artaban zaniepokojony snem; sc. 2: Daniel wyjaśnia sen Artabanowi. Akt II sc. 1: Nadab wyjawia Danielowi swoje zmartwienia; sc. 2: Artaban rozkazuje uwięzić Daniela; sc. 4: Azaf rzuca podejrzenia na Nadaba. Akt III sc. 2: Artaban poleca przyśpieszyć egzekucję Daniela; sc. 6: Aryzba nie poznaje Nadaba. Nadab pokazuje list od Daniela. Artaban wzywa Daniela z więzienia; sc. 8: Daniel wraca do więzienia. Nadab skazany na uwięzienie. Akt IV sc. 1: Beradan prosi o uwolnienie Daniela i Nadaba. Akt V sc. 1: żołnierze przynoszą głowę Azafa; sc. 3: Artaban usiłuje mie- 
czem zabić Nadaba; sc. 4: pojawia się Nabuch, Artaban odchodzi w gniewie; sc. 6: Beradan oznajmia śmierć Artabana.

Treść: Artabana dręczą sny i wzywa Daniela, by wyjaśnił ich znaczenie. Za namową Azafa postanawia sięgnąć po koronę królewską, tymczasem jego syn odwodzi go od tej decyzji. Daniel tłumaczy sen Artabanowi. Azaf przynosi wiadomość o zgromadzonym na zamku tłumie i Panach, a także o szerzącej się pogłosce o synu Nabucha, prawowitym dziedzicu tronu, przebywającym w pałacu Artabana. Nadab mówi Danielowi, co go trapi, Daniel go pociesza. Daniel odmawia wyjawienia Artabanowi, gdzie jest królewski syn, przez co zostaje uwięziony. Nadab bezskutecznie prosi o łaskę dla Daniela, tymczasem Azaf nakłania Artabana do ukarania Daniela i oskarża również Nadaba o zdradę. Artaban rozkazuje Azafowi przyśpieszyć egzekucję Daniela. Nadab prosi Artabana o rozmowę, podczas której wyjawia swoją tożsamość, do tej pory nieznaną dzięki działaniu Bożej mocy, Artaban jednak mu nie wierzy. Z Persji przybywa starzec Aryzba, który wychowywał Nadaba, ale nie poznaje w nim syna Nabucha. Artaban rozkazuje przyprowadzić Daniela, prorok jednak nie ujawnia prawdy i wraca do więzienia. Nadab również zostaje uwięziony. Beradan wstawia się za więźniami u ojca. Artaban rzekomo przychyla się do prośby syna, ale ukrywa przed nim zamiar zabicia Daniela i Nadaba. Artaban rozkazuje Azafowi przynieść ściętą głowę Daniela. Beradan prosi ojca, by pozwolił mu spotkać się w ogrodzie z królewiczem. Aryzba donosi Artabanowi o tym, co się wydarzyło w ogrodzie, ukrywa fakt zabicia Azafa z rozkazu Nabucha w taki sposób, że Artaban sądzi, iż mówi o śmierci Daniela. Żołnierze przynoszą głowę Azafa, a Aryzba oświadcza, że zginął z własnej ręki. Daniel powiadamia Artabana o przybyciu nowego króla. Nadab czyni Artabanowi wyrzuty za wyrok śmierci na niego i Daniela; Artaban po kłótni usiłuje go zabić mieczem. Do pałacu przybywa Nabuch i powstrzymuje Artabana przed zabiciem Nadaba; Artaban „pełen zemsty odchodzi”. Nabuch mówi synowi o karze. Beradan pełen żalu informuje Nabucha o śmierci swego ojca, który odebrał sobie życie, 
Nabuch rozkazuje go pochować i uroczyście zbudować ołtarz dla prawdziwego Boga.

K. $\left[\mathrm{a}_{2}\right] \mathrm{v}$.: „Komedya o dwu Starcach, z których Pantalon skąpy a Syna w osobliwszey karnośći chowający, Symo zaś hoyny, a swemu Pamfilowi pobłażający, uciesznemi postępkami różność natur w rodzoney Braći ukażą. Aż na koniec Symo chcąc Pantalona od wielkiey ku synom troskliwości i od skąpstwa odwieść, dóbr swoich Pamfila, którego był dawniey, potomka niemający, za Syna wźiął od Pantalona, dźiedźicem czyni, i hoyną ucztę sprawuje”.

Egzemplarze: Biblioteka Uniwersytecka w Wilnie, IV 24643.

3.

[Gorszwiłło Krzysztof?]: Cineres ad iustam vindictam animati a perillustri iuventute S. I. in scenam dati. Anno 1702, die 25 Februarii. [br. m. dr., Wilno?, Druk Akad. S.I.?, przed 25 II 1702]. 4.

K. nlb. 2, sygn. A .

[Tytuł nagłówkowy]: CINERES AD IUSTAM VINDICTAM ANIMATI Contra Voluptarium parricidam Popielum Secundum, Poloniae Principem. A Perillustri, Magnifica, ac Praenobili Rhetorica Iuventute Academica Societatis IESU, Ludis antecineralibus in Scenam dati. Anno 1702. 25 Febr:

Niżej: «Argumentum». K. $\left[\mathrm{a}_{1}\right] \mathrm{r} .-\left[\mathrm{a}_{2}\right] \mathrm{v}$.: tekst.

Język: łaciński.

Gatunek: tragedia.

Podzial: Prologus. Actus I sc. 1-6. Chorus. Intermedium. Actus II sc. 1-6. Chorus. Intermedium. Actus III sc. 1-5. Chorus. Intermedium. Actus IV sc. 1-6. Chorus. Intermedium. Actus V sc. 1-5. Epilogus.

Actus III sc. 2: saltus.

Osoby (brak spisu): Tyrannis; Ambitio; Nemesis; Troynadus, Stopełko, sororii Popieli; Popielus Secundus, Princeps Poloniae; patrui Popieli; sacrificuli; Zaslaus, Popieli frater; Pietas; Genius 


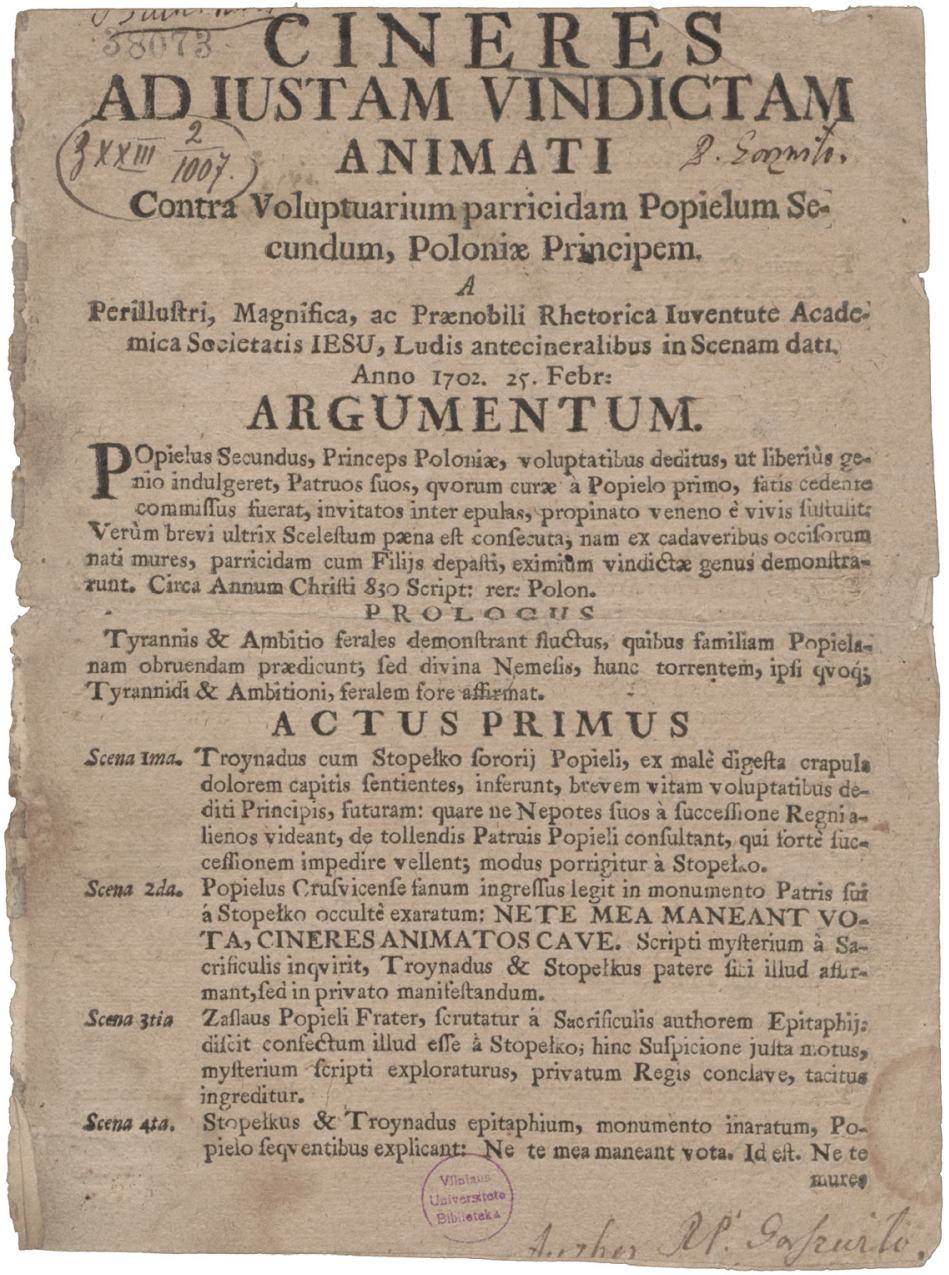

Cineres ad iustam vindictam animati, Biblioteka Uniwersytecka w Wilnie, sygnatura IV 31345. Za pozwoleniem biblioteki 
Familiae Popielanae; rustici; Lescus, filius Popieli; Premislus, filius Popieli; rusticus; Cordulus, filius Troynadi; Ephebi Moschovitici; Amor Patriae; venatores; aulici; hospites; arbitri; umbrae; mures.

Inscenizacja: Prologus: Tyrania i Ambicja ukazują złowróźbne fale. Actus I sc. 2: Popiel w świątyni czyta inskrypcję na pomniku swego ojca; sc. 3: Zasław ukrywa się w komnacie króla; sc. 4: Stopełko i Troynadus wyjaśniają Popielowi epitafium; sc. 6: Zasław w ubraniu pielgrzyma. Chór [1]: Tyrania i Ambicja topią Geniusza rodu Popiela. Actus II sc. 1: Zasław w domu Piasta; uczta wieśniaków; związany Zasław jest prowadzony do pałacu; sc. 2: Popiel zasypia przy stole; sc. 4: Zasław wtrącony do więzienia; sc. 5: wieśniak rzuca czar na Leszka i Przemysła, Stopełko przepędza ich z dworu; sc. 6: Stopełko przesłuchuje Zasława. Chór [2]: Geniusz rodu Popiela miotany falami. Actus III sc. 1: Stopełko pokazuje pismo Zasława; sc. 2: stryj Popiela wysyła mu młodzieńców moskiewskich; sc. 3: Stopełko posyła Zasławowi zatrute owoce; sc. 4: Przemysł i Leszek odwiedzają Stopełka, Leszek kosztuje zatrutych owoców, traci rękę. Chór [3]: Pobożność i Miłość do ojczyzny opłakują utopionego Geniusza rodu Popiela. Actus IV sc. 2: Troynadus opłakuje umierającego syna; sc. 4: goście przybywają na ucztę, Popiel udaje chorobę; sc. 5: Stopełko nasącza potrawy trucizną; sc. 6: stryjowie Popiela umierają otruci potrawami. Chór [4]: Tyrania i Ambicja toną. Actus V sc. 1: Troynadus przychodzi z myśliwymi w pałacu, wśród trupów Popielów pojawiają się myszy; sc. 3: Popiel, Stopełko, Leszek i Przemysł świętują powodzenie swoich zamiarów; sc. 4: ucieczka dworu przed myszami; sc. 5: Popiel opłakuje umierających synów, umiera z szaleństwa i cierpienia.

Treść: Prologus: Tyrania i Ambicja przepowiadają zagładę rodu Popiela. - Troynadus i Stopełko w trosce o swych wnuków snują plany usunięcia stryjów Popiela jako potencjalnych sukcesorów tronu po nim. Popiel w świątyni w Kruszwicy czyta na pomniku swojego ojca inskrypcję wyrytą skrycie przez Stopełka. Troynadus i Stopełko wyjaśniają mu znaczenie epitafium zgodnie ze swoją intrygą, tymczasem brat Popiela, Zasław, dowiaduje się od kapłanów, kto jest autorem inskrypcji, nabiera podejrzeń i udaje się potajemnie do komnaty króla, by usłyszeć rozmowę. Popiel, rozdarty między Tyranią 
a Pobożnością, wybiera drogę Tyranii, tymczasem Zasław postanawia powstrzymać zagładę swoją i krewnych i w przebraniu pielgrzyma udaje się do rodziny. Ubrany w ubogie szaty wchodzi do domu Piasta, gdzie ucztują wieśniacy, którzy zarzucają mu, że zdjąwszy szaty książęce, przywdział ubiór wieśniaczy, i prowadzą na dwór. Popiela, rozważającego swój zamysł, ogarnia melancholia. Kiedy wieśniacy przyprowadzają Zasława na dwór, twierdząc, że jest zbiegiem, w Popielu rodzi się podejrzenie, że jego podstęp wyszedł na jaw, stąd poleca Stopełkowi przesłuchać Zasława i wtrąca go do więzienia. Leszek i Przemysł, synowie Popiela, rozmawiają o sukcesji tronu po ojcu, wieśniak rzuca na nich czar, tak że nie poznają siebie nawzajem, a Stopełko, również ich nie poznając, przepędza ich z dworu. Zasław wyjawia Stopełkowi powód swojej ucieczki. Stopełko, oferując mu szansę ocalenia, skłania go do zeznania na piśmie, że Troynadus (którego nierozważnie wybrał na wspólnika swych intryg) rozgłaszał nienawiść Popiela do stryjów, pokazuje następnie to pismo Popielowi, a ten rozkazuje wywieźć Troynadusa $\mathrm{z}$ synem na pustkowie. Na dwór Popiela przybywają wysłani przez jednego z jego stryjów młodzieńcy moskiewscy, wyćwiczeni w tańcu swojego narodu. Stopełko posyła Zasławowi owoce nasycone trucizną, których kosztuje Leszek razem $\mathrm{z}$ bratem odwiedzający stryja w więzieniu. By trucizna nie opanowała całego ciała, Przemysł odcina mu rękę. Stopełko wyjawia Leszkowi i Przemysłowi zamiary swoje i Popiela, przekonuje ich, by zrzucili na Zasława winę za swoje nieszczęście. Po śmierci syna Troynadus postanawia zniweczyć plany Stopełka i Popiela. Kiedy przybywają stryjowie Popiela, ten udaje chorobę i wysyła synów na ich przyjęcie. Goście umierają z powodu zatrutych potraw, Popiel udaje smutek. Przybywa Troynadus. Wśród ciał pojawiają się myszy, wywołując panikę na dworze. Popiel, Stopełko, Leszek i Przemysł świętują sukces swoich zamiarów, ale ich radość burzy pojawienie się myszy. Popiel zdaje sobie sprawę, że powstały z ciał stryjów. Myszy są ćwiartowane, ale z pociętych kawałków powstaje ich jeszcze więcej. Stopełko i synowie Popiela giną zaatakowani przez myszy, sam Popiel ostatecznie umiera ogarnięty szaleństwem i bólem. Chór [1]: Tyrania z Ambicją topią Geniusza rodu Popiela, Pobożność usiłu- 
je go wyrwać z niebezpieczeństwa. Chór [2]: Geniusz rodu Popiela błaga o pomoc Tyranię, Ambicję i Pobożność. Chór [3]: Pobożność i Miłość do ojczyzny opłakują utopionego Geniusza rodu Popiela, Tyrania i Ambicja triumfują. Chór [4]: Tyrania i Ambicja, nie mogąc znieść złowrogich cieni, toną w falach.

Treść intermediów i epilogu niepodana.

Egzemplarze: Biblioteka Uniwersytecka w Wilnie, IV 31345. Prow. na k. $\left[a_{1}\right]$ r.: «P. Gorzwiło. Author R.P. Gorszwiło».

Uwaga: autorstwo na podstawie rękopiśmiennych uwag na egzemplarzu.

\section{4.}

Conviva bonae mentis Thomas, Arimensium dux, pro Christo victima factus, ludis antecineralibus in scenam datus a Iuventute Collegii Varsaviensis Societatis Iesu Anno Domini 1700 die 20 Februarii. [br. m. dr., Warszawa?, przed 20 II 1700]. $2^{\circ}$.

Estreicher XIV 398 (tu lokalizacja: Dzików).

K. nlb. 6, sygn. )2(-)3(.

[Tytuł]: CONVIVA BONAE MENTIS THOMAS, Victoriosissimus Arimensium Dux, Inter Convivales Epulas, pro CHRISTO Victima factus, atque sub fortunatissimis Auspiciis ILLUSTRISSIMI ac EXCELLENTISSIMI DOMINI, D. NICOLAI IOSEPHI, Comitis de Szczekarzewice \& Tęczyn TARŁO, Pincernae M.D.L. Goszczynensis, Brzegoviensis, \&c. \&c. CAPITANEI, Ludis Antecineralibus in Scenam datus, a Celsissima, Illustrissima, Perillustri, ac Praenobili Studiosa Juventute Collegii Varsaviensis Societatis JESV. Anno Domini 1700. die 20 Februarij.

Odwrót k. tyt.: drzeworyt, herb Tarłów «Topór», poniżej dystych elegijny i sześciowiersz w dystychu elegijnym na herb. K. )2(r.-)2(v.: dedykacja Mikołajowi Tarło, podpis: «Devinctissimum Collegium Varsaviense Societ. JESV». K. )3(r. «Fundamentum». K. )3(r.-[)4(]v.: tekst. 


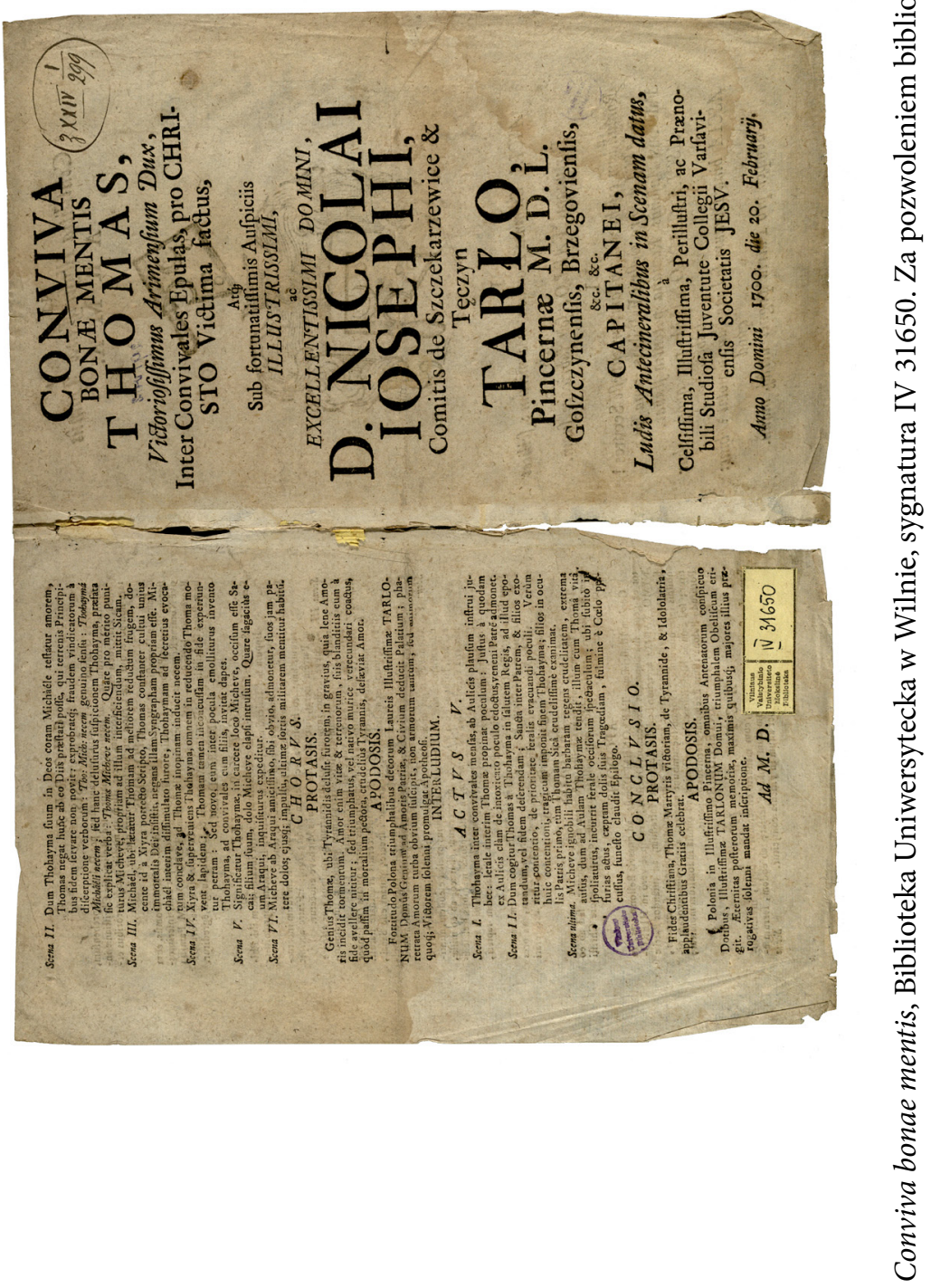


Język: łaciński.

Gatunek: tragedia ze wstawkami panegirycznymi.

Podzial: Prolusio I protasis, apodosis. Prolusio II protasis, apodosis. Actus I sc. 1-4. Chorus: protasis, apodosis. Interludium. Actus II sc. 1-5. Chorus: protasis, apodosis. Interludium. Actus III sc. 1-6. Chorus: protasis, apodosis. Interludium. Actus IV sc. 1-6. Chorus: protasis, apodosis. Interludium. Actus V sc. 1-2, ultima. Conclusio: protasis, apodosis.

Prolusio I protasis: «niebiańskie Gracje śpiewają pieśń triumfu»; apodosis: aplauzy Gracji sarmackich monarchów. Prolusio II protasis: aplauz Pogaństwa i Bałwochwalstwa, aplauz Chrześcijaństwa. Chorus [1] apodosis: aplauz Gracji monarchów polskich. Actus V sc. 1: aplauz dworzan. Conclusio: protasis: aplauz Gracji.

Osoby (brak spisu): Idololatria; Arimensis Monarchiae Gratiae; Dolus; Tyrannis; Thomae Genius; Religio; Christiana Fortitudo; colelestes Gratiae; Supremae Sarmaticae Dignitates; Merita; Martia Fortitudo; Genius Tarlonum Domus; Sarmatiae Monarcharum Gratiae; Aeternitas; Charon; Ethnicismus; Providentia Dei; Christianitas; Errores variarum Sectarum; Metropolitane Urbes Regni et Ducatuum; honores Ecclesiae; Stephanus Gnesnensis; Paulus Leopoliensis; Infulae Cracovienses, Vladislavienses etc.; Thomas Imperator; Michael Apostata, Arimensis regulus; Justus, Jacobus, Thomae filii; Thohayma, Arimae gubernator; Micheve iuvenis; Vocoxiura, Micheve frater; Philippus; Sacai, Thohaymae filius; Invidia; Fraus; Pietas; Gratitudo Patriae; Gratiae Monarcharum Poloniae; Thocaya; Xiyra, supremus Aulae Regiae Praefectus; Fama; florentissimae Familiae in Polonia et Lithuania; Fortitudo Polona; Araqui; Amor; turba Amorum; aulici; Polonia.

Inscenizacja: Prolusio I protasis: Idololatria przygotowuje ucztę, pojawia się Geniusz Tomasza; apodosis: najwyższe godności sarmackie zastawiają stól, Geniusz domu Tarłów wybiera potrawę Marsa. Prolusio II protasis: Charon tonie w płomieniach Styksu; apodosis: grzechy sekt kroczą do Polski, spotykają Geniusza domu Tarłów. 
Actus I sc. 1: Tomasz wkracza do miasta w triumfie; sc. 2: Thohayma zabija Vocoxiurę. Chorus [1] protasis: Geniusz Tomasza prowadzony do komnaty Honoru, Fraus i Dolus obdarowują go złotym naszyjnikiem; apodosis: Geniusz domu Tarłów wchodzi do bazyliki Zaszczytów. Actus II sc. 1: Sacai obdarowuje Filipa czarodziejskim pierścieniem; sc. 2: Filip i Justus wtrąceni do więzienia; sc. 5: Filip i Justus rozpoznają się. Chór [2] protasis: Geniusz Tomasza w labiryncie; apodosis: Sława przechadza się po ogrodzie. Actus III sc. 2: Jakub idzie w przebraniu do więzienia; sc. 3: Jakub połyka list od brata; sc. 4: Micheve zabija Filipa. Chór [3] apodosis: Mars na próżno powstrzymuje Geniusza domu Tarłów od obrony granic ojczyzny. Actus IV sc. 1: Micheve zakuwa Sacai w kajdany. Chór [3] protasis: Geniusz Tomasza torturowany przez Amora; apodosis: Geniusz domu Tarłów prowadzony do pałacu Miłości Ojczyzny i Obywateli. Actus V sc. 1: uczta, kielich z trucizną; sc. 2: Thohayma zabija Tomasza i jego synów; scena ostatnia: Micheve ginie rażony piorunem. Conclusio, apodosis: Polonia wznosi triumfalny obelisk.

Źródło: Nicolaus Trigautius, De christianis apud Japonias triumphis, liber 2, caput $3 \&$ 4, fol. 124; Mathias Tanner, Historia Asiatica ${ }^{27}$, fol. 366 .

Treść: Prolusio I: Idololatria i Dolus przygotowują ucztę i kielichy z trucizną, nadchodzi Geniusz Tomasza w towarzystwie Religio i Christiana Fortitudo i niszczy przepych uczty. Najwyższe godności sarmackie zastawiają stół, Martia Fortitudo ustawia triumfalną potrawę, którą wybiera Geniusz domu Tarłów. Prolusio II: Charon przybywa ku wybrzeżom Japonii, by wywieźć stąd dusze, ale Providentia Dei ustawia naprzeciw skałę, w którą Charon uderza i tonie w płomieniach Styksu. Grzechy różnych sekt zmierzają do Polski z sąsiednich państw, na widok Geniusza domu Tarłów tracą odwa-

27 Może chodzi o Societas Jesu usque ad sanguinis et vitce profusionem militans, in Europa, Africa, Asia, et America [...], Pragae: Typis Universitatis CaroloFerdinandae, 1675. 
gę i nadzieję. - Tomasz, dowódca wojsk królestwa Arimy, wkracza do miasta $\mathrm{z}$ łupami wojennymi. Król Michał Apostata obdarowuje go władzą nad Camum, synowie Tomasza, Justus i Jakub, zostają najwyższymi efebami. Thohayma, rządca Arimy, rozczarowany tą decyzją, razem z Micheve knuje zabicie króla i Tomasza. Słyszy to Vocoxiura i Thohayma zabija go. Kiedy Micheve usuwa ciało z drogi, przez znak na ręce rozpoznaje w zabitym swego brata i postanawia w zemście zabić Thohaymę. W tym celu skłania swojego sługę Filipa, by zaprzyjaźnił się z Sacai, synem Thohaymy. Filip i Sacai zawiązują głęboką przyjaźń, spiskują przeciw Justusowi i Jakubowi. Sacai obdarowuje Filipa pierścieniem, dzięki któremu może przybrać inną postać. Filip pod postacią Sacai spotyka Justusa, dochodzi do kłótni, naczelnik więzienia Thocaya wtrąca ich obu do celi. Michał próbuje bez skutku osłabić wiarę Tomasza różnymi łaskami. Xiyra, najwyższy urzędnik na dworze, wymusza od Tomasza wyznanie wiary na piśmie. Filip i Justus dzięki znakom na pierścieniach rozpoznają, że są braćmi. Filip wyjawia Justowi zasadzkę Micheve na króla i Tomasza. Sacai dowiaduje się o uwięzieniu Filipa, udaje się do Thohaymy, by go uwolnić. Jakub słyszy o uwięzieniu Filipa, idzie do więzienia w przebraniu i bierze listy brata do ojca, z których Tomasz poznaje intrygi Micheve. Ten spotyka Jakuba i próbuje mu wyrwać list, który tamten połyka, zostaje tylko skrawek z napisem Tho. Mich. śmierć. Micheve z obawy, że jego spisek wyszedł na jaw, zabija Filipa, sądząc, że to Sacai. Justusa przed ciosem chroni krucyfiks, jednak udaje martwego. Jakub pokazuje Tomaszowi skrawek kartki z napisem w obecności Micheve, który próbuje zatuszować przestępstwo fałszywą interpretacją liter. Tomasz rozkazuje uwięzić Micheve i uwolnić Justusa. Xyira przekazuje Michałowi wyznanie wiary Tomasza, zmieniwszy jego znaczenie. Król cieszy się z przewrotności Tomasza. Sacai wraca $z$ rozkazem uwolnienia Filipa. Znajduje tylko Micheve, który wyciąga jego miecz i podstępem zakuwa go w kajdany. Tomasz tłumaczy Michałowi znaczenie podartej kartki jako Thohayma Michałowi śmierć, Thohayma $\mathrm{z}$ kolei jako Micheve Tomaszowi śmierć, postanawiając ukarać Micheve. Tomasz zaprzecza, że wyrzekł się wiary w Boga, Michał wpada w szał i skłania Thohaymę do zabicia 
Tomasza. Thohayma dowiaduje się, że w więzieniu zamiast Micheve został zabity Sacai. Araqui mówi Micheve, że jego intrygi wyszły na jaw. Podczas uczty Thohayma podaje Tomaszowi kielich z trucizną. O podstępie dowiaduje się Justus. Gdy Thohayma zmusza Tomasza do toastu za zdrowie króla, synowie Tomasza chcą pierwsi opróżnić zatruty kielich i powstaje spór, któremu kres kładzie Thohayma, zabijając synów Tomasza, a następnie jego samego. Micheve pojawia się na dworze Thohaymy, by zabić jego i Tomasza. Widząc martwych Tomasza z synami, wpada w szał i zostaje rażony piorunem. Wiara chrześcijańska święci zwycięstwo Tomasza męczennika nad Tyranią i Bałwochwalstwem. Treść protasis i chórów związana $\mathrm{z}$ akcją, apodosis o charakterze panegirycznym. Chór [1]: Geniusz Tomasza prowadzony do komnaty Honoru w towarzystwie Invidia. Fraus i Dolus wychodzą mu naprzeciw i obdarowują złotym naszyjnikiem. Tomasz przekazuje prezent Invidia, która wpada w niewolę Fraus i Dolus. Geniusz domu Tarłów stąpa po głowach Invidia, Fraus i Dolus, w towarzystwie Fortitudo i Pietas wchodzi do bazyliki Zaszczytów. Gratitudo Patriae wymienia zasługi domu Tarłów, podjęte misje poselskie i wspaniałość otrzymanych zaszczytów. Chór [2]: Idololatria w labiryncie usiłuje wplątać Geniusza Tomasza w sieci grzechów. Uczy, że Geniusz Tomasza nawet wśród grzechów nie może zbłądzić. Fama przechadza się po ogrodzie domu Tarłów w towarzystwie najsławniejszych rodów w Polsce i na Litwie, zbiera kwiaty zapisane imionami królów i wychodzi bramą rodową Ogińskich. Chór [3]: Tyrannis usiłuje groźbami odwieść Geniusza Tomasza od Chrystusa, ale wyszydzona przez niego groźbami pojmuje, że dla niego wszystko jest bezpieczne, bo w pogardzie ma niebezpieczeństwa dzięki samej miłości do Chrystusa. Mars na próżno usiłuje powstrzymać Geniusza domu Tarłów od obrony granic ojczyzny. Fortitudo Polona pokazuje go jako wzór bohaterom. Chór [4]: Gdy Geniusz Tomasza pokonał szał Tyrannis, wpadł w tortury Amora. Amor vitae et terrenorum daremnie próbuje odciągnąć Geniusza Tomasza od wiary. Fortitudo Polona prowadzi Geniusza domu Tarłów do pałacu Miłości Ojczyzny i Obywateli. Tłum Amorów z kołczanami ogłasza go w uroczystej apoteozie zwycięzcą broni i serc. Conclusio, apodosis: 
Polonia w podczaszym wznosi triumfalny obelisk dla domu Tarłów. Aeternitas pisze uroczystą inskrypcję.

Treść interludiów niepodana.

Egzemplarze: Biblioteka Uniwersytecka w Wilnie, IV 31650.

\section{5.}

Corona civica, Salvatori in Gobrya, Principe Persa, oblata. [br. r. i m. dr.]. $2^{\circ}$.

K. nlb. i nsygn. 1, [a $]$.

[Tytuł nagłówkowy]: CORONA CIVICA, SALVATORI Civium, et omesticorum DEI, DEO INCARNATO CORPVS SVVM IN VINDICTAM HVMANAE LIBERTATIS IN PASSIONE TRADENTI IN Gobrya, Principe Persa, oblata.

Niżej: «Fundamentum». K. [a $\left.{ }_{1}\right]$ r.-v.: tekst.

Język: łaciński.

Gatunek: dramat.

Podział: Prologus. Prothasis. Pars I ind. 1-5. Pars II ind. 1-5. Pars III ind. 1-9. Apodosis. [Listwa z ozdobników druk.].

Osoby (brak spisu): Cambyses, Persiae rex; Faxaflandus; Scytha captivus; Maginus Senator; Cyrus rex; Aegypti; Ammoni; Mergis, Cambysis frater; Cometes Magus; Oropastes, Cometis frater; Ostanus, satrapa Persiae; Hipsipylus, ephebus regius; Nigrantulus, Ostani cliens; aulici; septem Persiae satrapae; Gobryas, Persiae princeps.

Inscenizacja: Pars I ind. 3: jeniec scytyjski publicznie krytykuje okrucieństwo Cyrusa; ind. 4: senator Maginus zabija Scytę. Pars II ind. 2: Maginus przynosi królowi głowę Cyrusa, zostaje zabity, umiera Kambyzes; ind. 4: ogród, Cometes podaje Mergisowi śmiertelną truciznę; ind. 5: Oropastes zabija Mergisa i zakłada jego szaty, udając jego samego. Pars III ind. 2: Ostanus posyła Nigrantulusa na dwór; ind. 4: Cometes zasypia; ind. 6: Cometes zbudzony ze snu, pojawia się Oropastes udający Mergisa; ind. 9: Gobryas chwyta Cometesa, rozkazując przebić swe ciało, by zabić fałszywego króla. 


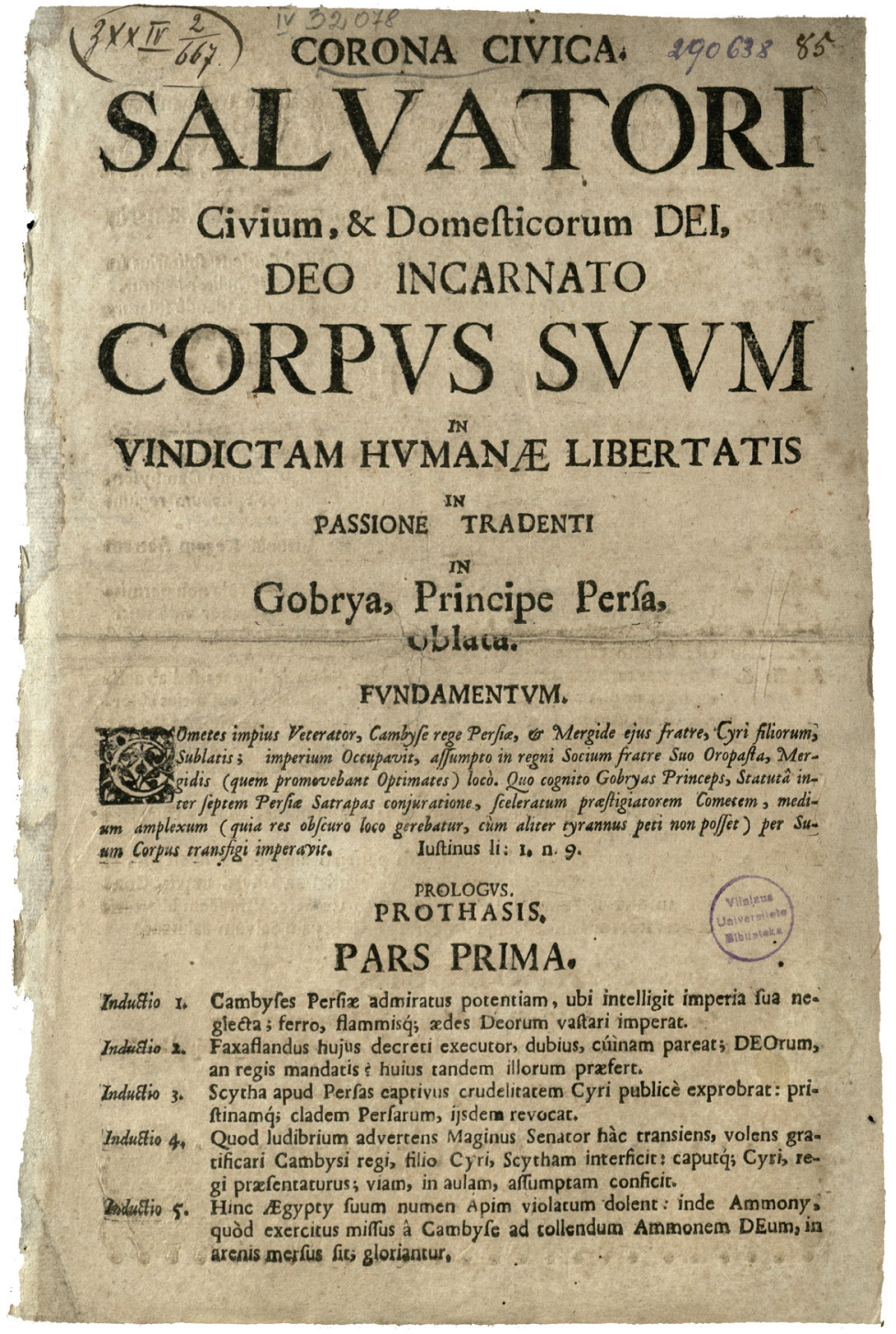

Corona civica, Biblioteka Uniwersytecka w Wilnie, sygnatura IV 32078. Za pozwoleniem biblioteki 


\section{Źródło: Iustinus, 1. 1, n. 9.}

Treść: Kambyzes, zdając sobie sprawę, że jego rozkazy są lekceważone, zarządza zniszczenie świątyń bogów. Faxaflandus, wykonujący królewskie zarządzenie, wahając się, czy być posłusznym bogom czy królowi, ostatecznie ulega rozkazowi króla. Jeniec scytyjski publicznie krytykuje okrucieństwo Cyrusa, senator Maginus, słysząc to, postanawia przysłużyć się Kambyzesowi i zabija Scytę, a głowę Cyrusa zanosi królowi do pałacu. Egipcjanie użalają się z powodu zbezczeszczenia ich boga Apisa, Ammończycy chełpią się, że wojsko wysłane przez Kambyzesa w celu usunięcia Ammona zginęło w piaskach. Kambyzes ma widzenie senne, że jego brat Mergis obejmie tron, rozkazuje więc Cometesowi go zabić. Kiedy Maginus przynosi głowę Cyrusa i napomina króla, by nie zabijał brata, sam zostaje zabity. Kambyzes, wyciągnąwszy miecz, popełnia samobójstwo. Cometes na wieść o tym spiskuje ze swym bratem Oropastesem, postanawia usunąć Mergisa i przejąć władzę w Persji. Mergis nie wie o śmierci brata; gdy przebywa w ogrodzie, Cometes podaje mu śmiertelną truciznę. Oropastes dowiaduje się o cierpieniu Mergisa, pociesza go, a potem zabija. Ubrawszy się w purpurę królewską, udaje samego Mergisa. Cometes skłania przygnębiony dwór do potajemnego pogrzebu Kambyzesa, sam tymczasem zostaje wybrany królem i nazwany Kambyzesem. Ostanus podejrzewa, że królem w rzeczywistości jest Cometes, a nie prawdziwy Kambyzes. Przez Hypsipylosa wysyła Nigrantulusa, by zbadał sprawę. Oropastes rozkoszuje się swoim sukcesem. Cometes zasypia, rozważając swoje położenie, tymczasem Hypsipylos poznaje, że król nie ma uszu. Cometes budzi się, sądząc, że ktoś szczypie go w uszy, wezwani dworzanie uznają, że to wymysły. Wchodzi Oropastes udający Mergisa, „nowy Kambyzes” nakazuje radość w całej Persji, odprawia dwór. Ostanus, dowiedziawszy się o oszustwie Magów, powiadamia o tym siedmiu możnowładców królestwa i razem postanawiają zabić fałszywych władców. Gobryas stojący na czele spisku obejmuje Cometesa i rozkazuje przebić swe ciało, by miecz dosięgnął Maga. Po zabiciu Cometesa satrapowie na- 
zywają ocalałego Gobryasa odkupicielem wolności i zbawcą ojczyzny. Apodosis czci zbawcę i odkupiciela ludzkiej wolności.

Treść prologu i prothasis niepodana.

Egzemplarze: Biblioteka Uniwersytecka w Wilnie, IV 32078.

6.

Corona religionis orthodoxae in S. Stephano primo Pannoniae Catholicae Rege coronato in scenam data, Nicolao Stephano Pac dedicata a perillustri iuventute Academiae Vilnensis S.I. Anno Domini 1682 mense Octobri. [X 1682, br. m. dr., Wilno?, Druk Akad. S.I.?,]. $2^{\circ}$.

K. nlb. i nsygn. 2, $\left[\mathrm{a}_{2}\right]$.

[Tytuł]: CORONA RELIGIONIS ORTHODOXAE in S. STEPHANO primo $\mathrm{Pa}[\mathrm{n}]$ noniae Catholicae Rege coronato in Scenam data, Illustrissimo ac Reverendissimo Domino, D. NICOLAO STEPHANO PAC DEI \& Apostolicae Sedis Gratia Episcopo Vilnensi, SSmi D.N. INNOCENTII Divina Providentia PAPAE XI Praelato Domestico, Protonotario Apostolico, Utriusq[ue] Signaturae Gratiae \& Iustitiae Referendario, Sacri Palatij Comiti, \& Ecclesiae Later: Eqviti Aurato, \&c. \&c. Dum post obtentam annuente suis meritis Roma, Praesuleam coronam triumpharet, DEDICATA a Perillustri Praenobiliq[ue] Iuventute Academiae Viln: Soc: IESV. Anno Domini 1682 Mense Octobri die.

Odwrót k. tyt.: «Argumentum». K. [a $]$ v.- $\left[a_{2}\right]$ v.: tekst.

Język: łaciński.

Gatunek: dramat.

Podział: Antiprologus. Prologus. Actus I sc. 1-7. Chorus. Interludium. Actus II sc. 1-6. Chorus. Interludium. Actus III sc. 1-5. Chorus. Interludium. Actus IV sc. 1-5. Chorus. Interludium. Actus V sc. 1-4. Epilogus.

Chorus [1]: „saltu applaudunt Fauni”. Chorus [2]: „saltus aulicus applaudit”. Chorus [3]: „saltus anagrammaticus”. Chorus [4]: „ferae saltu applaudunt". 


\section{CORONA}

RELIGIONIS ORTHODOX屟

In S.STEPHANO primoPănoniz

Catholicæ Rege coronato

in Scenam data,

Illuftriffimo ac Reverendiffimo Domino,

D. NICO LAO STEPHANO

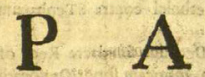

DEI \& Apoftolicæ Sedis Gratia Epificopo Vilnenfi, SSmi D.N. INNOCENTII Di. viná Providentiá PAP A XI Pralato Domeftico, Protonotario Apoftolico, Utriufq; כìgnaturæ Gratiæ \& luftitiæ Referendario, $\mathrm{Sa}$. cri Palatij Comiti, \&x Ecclefix Later:

Eqviti Aurato, \&c. \&c.

Dum poft obtentam annuente fuis meritis Roma, Prefuleam coronam triumpharet,

\section{DE D I C A T A}

A Perillufri Prenobiligi; Iwventute Academis Viln: Soc:IEST. $\therefore$ Anno Domini I682 Menjo Octobri dic

Corona religionis orthodoxae, Litewska Biblioteka Narodowa im. Martynasa Mazvydasa, sygnatura KE 819917. Dostępne w bibliotece cyfrowej www.epaveldas.lt: http://www.epaveldas.lt/object/recordDescription/LNB/ C1B0000921650 (dostęp: 22.09.2017) 
Osoby (brak spisu): Genius Praesuli; Hydra; Religio; quattuor Cardinales Virtutes; Honor; Aquila; Stephanus Rex; Otho Imperator; Amornus, Coronus, Principes Hungariae; sacrificuli; Furiae infernales; Cordanus, Othonis patruelis; Zusianus, belli dux; Delphinus, Cordani filius, Imperatoris nepos; Adolphus, Carinus, Stephani Regis patrueles; Haeresis; Fauni; cervus; Bovinus, servus Amorni; venatores; Fortuna; Genius Pacianus; patritii iuvenes; fictus eremita; Cordulus, Amorni filius; Angelus; ferae.

Inscenizacja: Antiprologus: Geniusz biskupa depta Hydrę herezji, Religio na triumfalnym rydwanie. Prologus: Honor na skrzydłach orła zanosi Stefanowi koronę. Actus I sc. 7: las, Amornus, Coronus i Cordanus przebierają się za pustelników i pasterzy. Chorus [1]: Haeresis przebiera się za wilka. Actus II sc. 1: polowanie; sc. 2: Adolpus i Carinus toną w rzece; sc. 3: Bovinus ratuje tonących; sc. 4: prorocze słowa jelenia. Chorus [2]: Honor umieszczony przy ołtarzu. Actus III sc. 1: Amornus pokazuje królowi szaty książąt; sc. 3: lilie z inskrypcją; sc. 5: Bovinus zamienia zmyślony list Amornusa. Chorus [3]: Fortuna i Religio sadzą lilie. Actus IV sc. 1: Zusianus uwalnia Delphinusa; sc. 4: Cordulus daje Zusianusowi list zamieniony przez Bovinusa. Chorus [4]: dzikie zwierzęta czynią między sobą znak pokoju i przyjaźni. Actus V sc. 1: Zusianus zakuwa w kajdany Amornusa, Coronusa i Cordanusa; sc. 3: Anioł splata wieniec dla modlącego się Stefana; sc. 4: Otho koronuje Stefana. Epilogus: Geniusz biskupa na triumfalnym rydwanie.

Źródło: Bonf. et Surius in Vita eius.

Treść: Antiprologus: Geniusz biskupa depta Hydrę herezji, Religio na triumfalnym rydwanie razem z czterema kardynalnymi cnotami zaprasza go do infuły. Prologus: Religio budzi Honor i poleca zanieść Stefanowi koronę. Honor leci na skrzydłach orła. - Król Stefan razem z cesarzem Ottonem i książętami Amornusem i Coronusem rozważają postęp wiary katolickiej i koronację Stefana. Nadlatuje orzeł z koroną i napisem: „Miłość do korony”. Amornus i Coronus, skryci poganie, knują spisek na Stefana. Kapłani pogańscy, czując 
urazę do króla z powodu zniszczonych wizerunków bogów, sprowadzają na Amornusa i Coronusa sen i podburzają ich do buntu i zemsty. Zabierają Amornusowi pismo króla, w którym wzywa senatorów do przyjęcia wiary chrześcijańskiej, i zastępują innym, w którym pozwala na czczenie bogów. Amornus i Coronus, sądząc, że panowanie nad Węgrami przypadnie im w udziale, knują intrygę przeciw królowi i wprowadzają w swe plany Cordanusa, kuzyna Ottona, który zrzeka się wiary w Chrystusa. Do spisku dołącza zwiedziony przez Cordanusa Zusianus. Przygotowując w lesie zasadzkę na Delphinusa, Adolphusa i Carinusa, udających się na polowanie, przebierają się za pustelników i pasterzy. Delphinus, Adolphus i Carinus w pogoni za jeleniem słyszą jego głos i ostrzeżenie. Amornus i Coronus topią w rzece Adolphusa i Carinusa, a Delphinusa przywiązują do drzewa. Bovinus, sługa Amornusa, lituje się nad ich losem, ratuje tonących i w przebraniach pasterzy wyprawia na dwór. Amornus, Coronus i Cordanus, słysząc przepowiednię jelenia, uznają ją za zapowiedź przyszłych rządów w królestwie i dzielą władzę między sobą. Kiedy myśliwi szukają książąt, Amornus i inni spiskowcy mówią, że udali się na dwór po drugiej stronie rzeki. Cordanus szykuje śmierć Delphinusowi, twierdząc, że Bóg mu ją objawił. Amornus pokazuje królowi szaty książąt i mówi, że znalazł je na brzegu rzeki, a książęta utonęli podczas kąpieli. Tymczasem książęta nierozpoznani $\mathrm{z}$ powodu pasterskich ubrań zostają przepędzeni z dworu. Amornus, zdziwiony, że żyją, ponownie oddaje ich pod straż Bovinusa. Kiedy młodzież ofiarowuje zmarłym książętom kwiaty, nagle wyrastają trzy lilie z inskrypcją „Książęta żyją”. Amornus i Coronus nakłaniają króla i cesarza, by zasięgnęli rady fałszywego pustelnika w sprawie książąt i sukcesji tronu. Amornus tymczasem przy pomocy swego syna Cordulusa pieczętuje królewskim pierścieniem zmyślony list o treści wymierzonej w króla. Bovinus wyjawia Adolphusowi i Carinusowi spisek Amornusa, zabiera Cordulusowi list i zastępuje go innym, oczerniającym Amornusa. Związany w lesie Delphinus słyszy we śnie prorocze słowa, uwalnia go Zusianus szukający eremity. Fałszywy pustelnik zwodzi Zusianusa, króla i cesarza fałszywymi przepowiedniami, wskazując na Amornusa i Coronusa jako sukcesorów tronu węgierskiego oraz Cordanu- 
sa jako współcesarza. Zusianus otrzymuje list przeciw Amornusowi i poznawszy zamysły spiskowców, zaprasza ich na dwór; tymczasem wyjawia królowi ich zbrodnie. Książęta wracają na dwór. Zusianus podstępem zakuwa Amornusa, Coronusa i Cordanusa w kajdany. Król powstrzymuje Bovinusa, który chce ukarać Cordulusa śmiercią za użycie pieczęci na zgubę króla. Kiedy Stefan się modli, Anioł splata dla niego wieniec z lilii i wyjaśnia znaczenie słów „Miłość do korony”. Buntownicy wracają do wiary chrześcijańskiej i posłuszeństwa królowi. Otton koronuje Stefana koroną przesłaną przez papieża. Następuje rozpoznanie: Delphinus jest synem Cordanusa, Amornus i Coronus braćmi Adolphusa i Carinusa. - Epilog: Geniusz biskupa na triumfalnym rydwanie otrzymuje od Fortuny koło szczęścia i złoty łańcuch lat. Chór [1]: Haeresis w przebraniu wilka zastawia pułapkę na Fides pod postacią baranka, ale Geniusz biskupa ją przepędza. Salt Faunów. Chór [2]: Religio i Fortuna ratują tonący Honor i umieszczają przy ołtarzu pod opieką Geniusza Paców. Salt dworski. Chór [3]: Fortuna i Religio z czterema cnotami kardynalnymi sadzą lilie otrzymane od Geniusza Paców. Salt anagramatyczny. Chór [4]: dzikie zwierzęta, z natury sobie wrogie, czynią znak pokoju i przyjaźni. Salt dzikich zwierząt.

Treść interludiów niepodana.

Egzemplarze: Litewska Biblioteka Narodowa im. Martynasa Mazvydasa, KE 819917. 


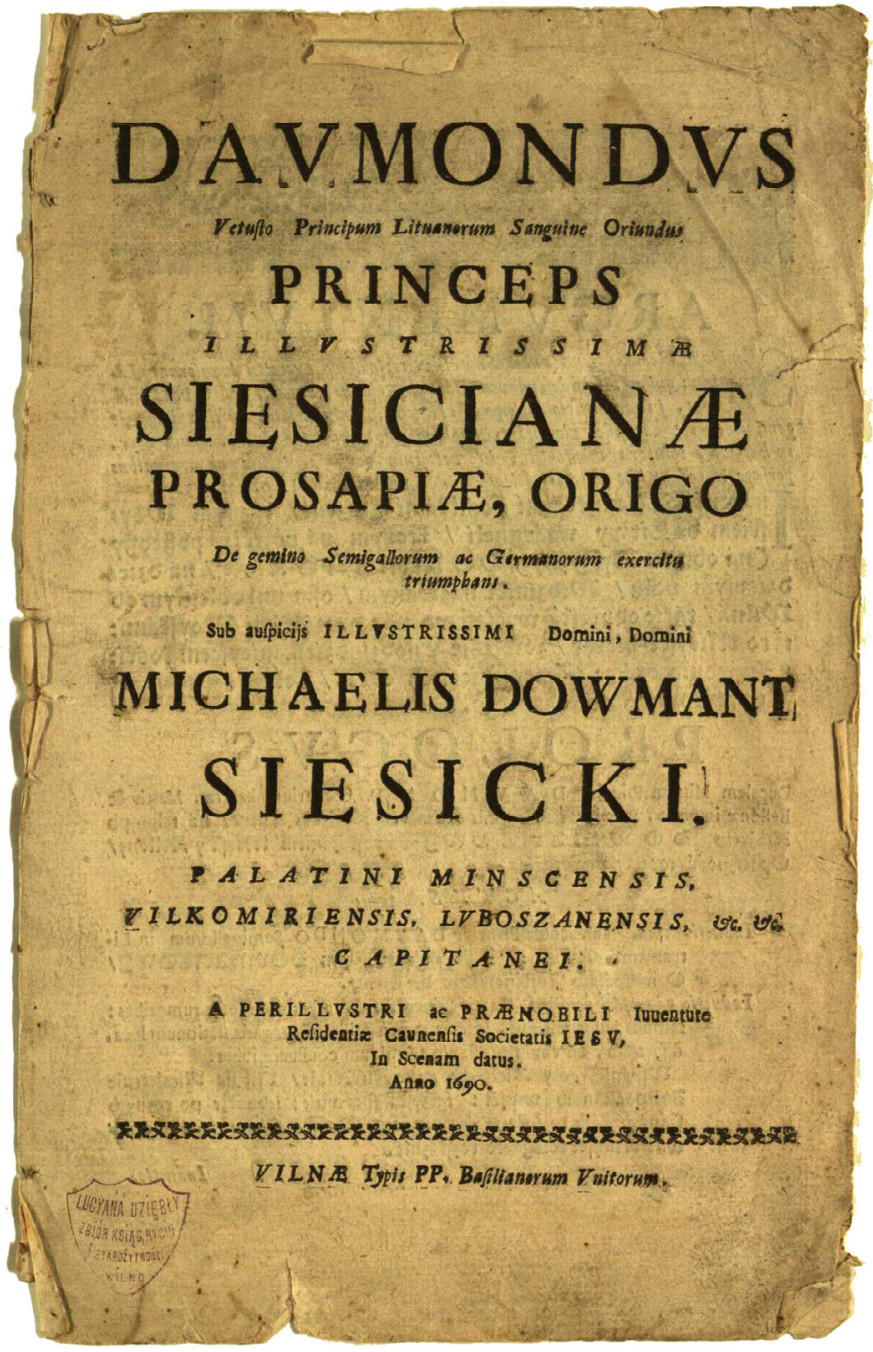

Daumondus, Litewska Biblioteka Narodowa im. Martynasa Mazvydasa, sygnatura KE 9274/1690. Dostępne w bibliotece cyfrowej www.epaveldas.lt: http://www.epaveldas.lt/object/recordDescription/LNB/C1B0000921969 (dostęp: 22.09.2017) 


\section{7.}

Daumondus vetusto principum Lituanorum sanguine oriundus princeps, illustrissimae Siesicianae prosapiae origo, sub auspiciis Michaelis Dowmant Siesicki a iuventute Caunensis Societatis Iesu, in scenam datus, anno 1690. Wilno, Druk. Bazylianów. [1690]. $2^{\circ}$. K. nlb. i nsygn. 2, $\left[\mathrm{a}_{2}\right]$.

[Tytuł]: DAVMONDUS Vetusto Principum Lituanorum Sanguine Oriundus PRINCEPS ILLVSTRISSIMAE SIESICIANAE PROSAPIAE, ORIGO De gemino Semigallorum ac Germanorum exercitu triumphans. Sub auspicijs ILLVSTRISSIMI Domini, Domini MICHAELIS DOWMANT SIESICKI. PALATINI MINSCENSIS, VILKOMIRIENSIS, LVBOSZANENSIS, \&c. \&c. CAPITANEI. A PERILLVSTRI ac PRAENOBILI Iuuentute Residentiae Caunensis Societatis IESV, In Scenam datus. Anno 1690. [Listewka z ozdobników druk.] VILNAE Typis PP. Basilianorum Vnitorum.

Odwrót k. tyt.: [Listwa z ozdobników druk.] «Argumentum». K. $\left[a_{1}\right]$ v. $-\left[a_{2}\right] v .:$ tekst.

Język: łaciński i polski.

Gatunek: dramat z elementami panegirycznymi.

Podział: Prologus. Actus I ind. 1-3. Chorus. Interludium. Actus II ind. 1-3. Chorus. Interludium. Actus III ind. 1-3. Epilogus.

Actus I ind. 2: festivi ludi. Actus III ind. 3: „miles plausu, Sylvanus chorea silvestri applaudit".

Osoby (brak spisu): Daumondus Princeps; Providentia; Mars?; Bellona?; milites; Semigallorum exercitus; captivus; Germani.

Inscenizacja: Prologus: Providentia ozdabia klejnotami książęcą mitrę. Actus I ind. 2: Daumondus urządza igrzyska; ind. 3: wojsko inflanckie wkracza na Litwę. Actus II ind. 1: Daumondus idzie $\mathrm{z}$ wojskiem przeciw nieprzyjacielowi; ind. 2: ćwiczenia wojskowe. Actus III ind. 1: bitwa; ind. 2: ucieczka Niemców.

Źródło: Strykovius 1. 9, fol. 355. 
Treść: Prologus: z rozkazu Marsa i Bellony Providentia ozdabia klejnotami książęcą mitrę na triumf Daumondusa. - Daumondus otrzymuje wiadomość o wtargnięciu wojsk inflanckich na Litwę. Książę urządza igrzyska, w tym samym czasie rozkazuje rozproszonemu wojsku zebrać się w jednym miejscu. Wojsko inflanckie wkracza na ziemie litewskie. Przed Daumondusem staje jeniec i opisuje liczbę wojsk nieprzyjacielskich i ich uzbrojenie. Daumondus wyrusza z wojskiem, by stawić czoła wrogowi. Odbywają się ćwiczenia wojskowe, armia jest ustawiana w szyku bojowym, urządzane są zasadzki na nieprzyjaciela. Dochodzi do bitwy, Niemcy uciekają, jedni giną, inni wpadają w zasadzki. Daumondus zwycięża, żołnierze czynią aplauz, Fauni odprawiają leśny taniec. - Epilog: naucza, że dla innych Mars i Bellona są zmienni, wojewodzie mińskiemu nigdy nie pozwalają opuścić pola walki bez zwycięstwa. Chorus [1]: ze względu na gotowość Daumondusa do wojny chwali gotowość wojenną wojewody mińskiego. Chorus [2]: z okazji wyprawy wojennej Daumondusa wymienia najchwalebniejsze wyprawy wojenne wojewody mińskiego.

Treść interludiów niepodana.

Egzemplarze: Litewska Biblioteka Narodowa im. Martynasa Mazvydasa, KE 9274/1690. Prow.: pieczątka na karcie tyt.: Lucyana Uziębły zbiór ksiąg, rycin i starożytności. Wilno. Druga pieczątka na k. $\left[\mathrm{a}_{2}\right] \mathrm{v}$ : [...] Lucyana Uziębły w Wilnie. Odręczne notatki na k. [a $\left.a_{2}\right]$.: „Abrenuntio tibi Satana, et coniungo tibi Chryste" (dalej nieczytelne). Egzemplarz naddarty na brzegach.

Biblioteka Wróblewskich w Wilnie, L-17/2-7/2.

Biblioteka Wróblewskich w Wilnie, L-17/2-9, Prow.: pieczątka na k. $\left[a_{1}\right]$ v. i k. $\left[a_{2}\right]$ v.: Lietuvos TSR Mokslų akademijos Centriné biblioteka. Pieczątka na k. [a $\left.a_{2}\right]$ v:: Książnica Towarzystwa Przyjaciół Nauk w Wilnie.

Uwaga: oba egzemplarze z Biblioteki Wróblewskich w klocku z Theatrum perennantis gloriae [...] Michaeli Dowmant Siesicki a [...] iuventute residentiae Caunensis Soc. Iesu, per canoras Musas exci- 
tatum anno 1690 - poematem zawierającym legendę wywodzącą Siesickich od księcia Dawmonda oraz życiorysy i portrety wybitniejszych przodków.

\section{8.}

Divina iustitia scelerum vindex in quodam improbo Russiae principe in scenam data a perillustri iuventute Collegii Posnaniensis S.I. anno 1718 mense Iulio. [br. m. dr., Poznań?, VII 1718]. $2^{\circ}$.

K. nlb. 2, sygn. (2).

[Tytuł nagłówkowy]: DIVINA JUSTITIA SCELERUM VINDEX, In quodam improbo Russiae Principe OLIM EXHIBITA, Nunc vero te[m]pore Generaliu[m] Majoris Poloniae Judicioru[m] IN SCENAM DATA, A Perillustri Juventute Humanitatis, Clari Collegii Posnaniensis Soc. JESV; Anno Solis Justitiae 1718. Mense Julio.

Niżej: «Argumentum». K. (1)v.-K. (2)v.: tekst.

Język: łaciński i polski.

Gatunek: tragedia.

Podział: Antiprologus. Prologus. Actus I sc. 1-2, intermedium, sc. 3-5. Actus II sc. 1-2, intermedium, sc. 3-5. Chorus. Actus III sc. 1-4, chorus, sc. 5-7. Epilogus.

Antiprologus: przyśpiew chóru. Actus II sc. 1: salt Francuzów przy dźwięku instrumentów muzycznych. Actus III sc. 2: „bieg kopijny do pierścienia”. Actus III sc. 3: „rycerski skok kawalerii”. Actus III sc. 4: „Fortunny skok”; taniec księcia ze Zbytkiem i dwiema śmierciami.

Osoby: Nemesis; Mors; Chorus; Princeps Progenitor; Principis Filius; Proceres; Genius Regnorum; Paedagogi; Professor; Daemon; Galli; Sodales; amici hospites; aulici; Angelus Custos; monstra infernalia (?); Cataphracti; ephebi; Luxus; binae mortes; Angelus vindex; Angelus.

Inscenizacja: Antiprologus: Nemezis niszczy trofeum Zbytku, pojawia się śmierć z wężami, „pół teatru nagle przybiera smutną twarz”. Actus I sc. 1: prezentacja znaków męstwa; sc. 2: wizyta senatorów; 


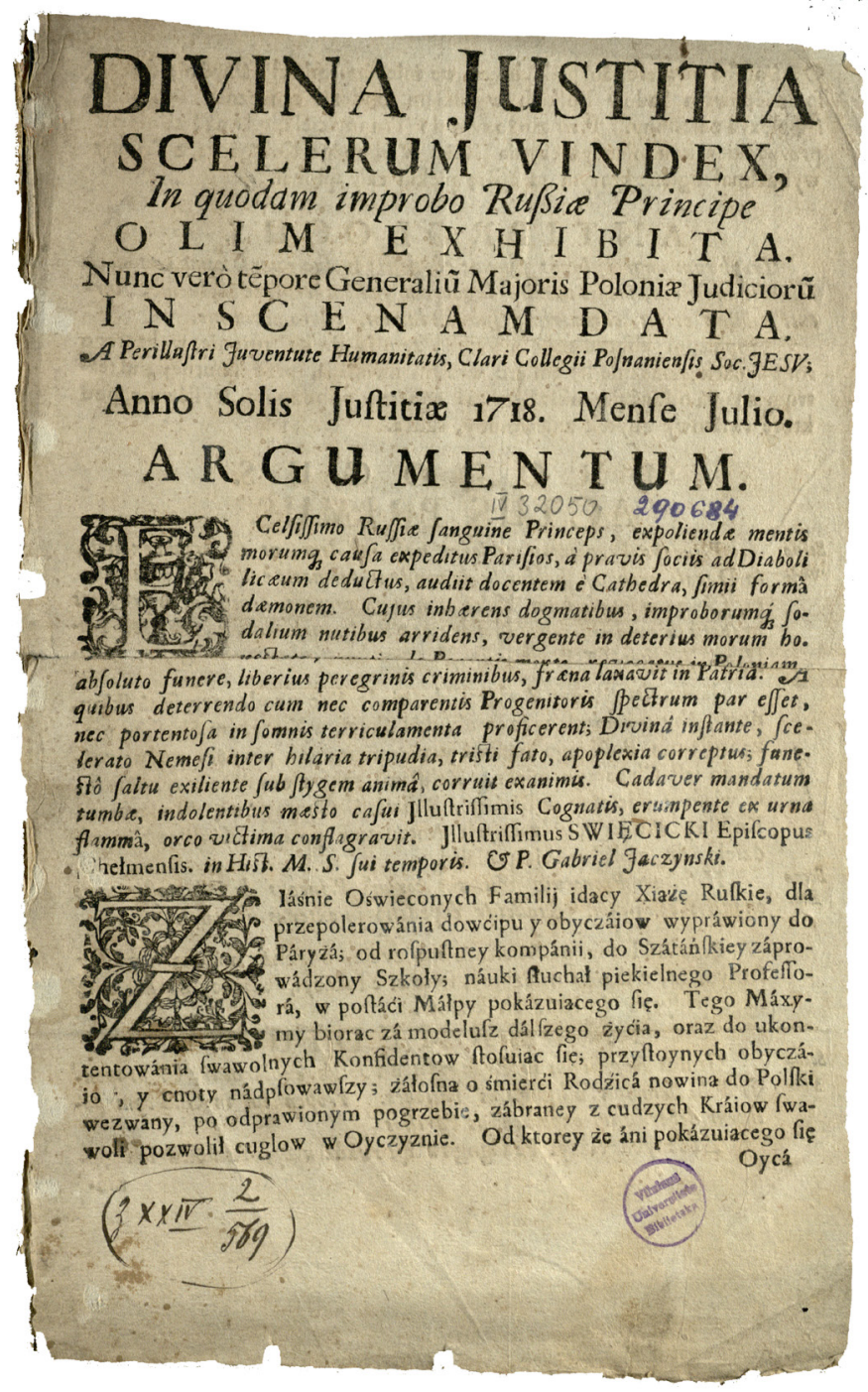

Divina iustitia scelerum vindex, Biblioteka Uniwersytecka w Wilnie, sygnatura IV 32050. Za pozwoleniem biblioteki 
sc. 4: podróż do Paryża. Actus II sc. 1: podziemna szkoła; sc. 3: pogrzeb, cały teatr nagle przybiera żałobę; stypa; sc. 5: pijatyka. Actus III sc. 2: cały teatr zmienia się nagle w ogród; sc. 5: ukazuje się Anioł zemsty, książę umiera ze strachu; sc. 6: piorun bucha z trumny; sc. 7: męki księcia w piekle.

Źródło: biskup chełmski Stanisław Jacek Święcicki, „Hist. M.S. sui temporis"; P. Gabriel Jaczyński.

Treść: Antiprologus: kiedy Nemezis niszczy trofeum Zbytku, z ruin ukazuje się śmierć opleciona wężami. Nemezis buduje okazalszy pomnik cnocie i rzuca u jego stóp Zbytek skrępowany łańcuchem. Książę rodzic chce zachęcić syna do szlachetnego postępowania i pokazuje mu w książęcym skarbcu miecz Chobrego [!], złotą rękę Żelisława, chorągiew Radwana, kopię Mieleckiego, puklerz i posągi przodków. W czasie odwiedzin senatorów pyta o radę w kwestii wychowania syna, postanawia wysłać go za granicę. Sprowadza pedagogów z różnych krajów, by wybadać skłonności syna, który okazuje sympatię dla Francji. Książę syn zostaje wysłany do Paryża, gdzie przyjmuje go do szkoły Profesor. Książę uczy się przy zegarze Alfonsa zwanym „Życie księcia”. Współuczniowie prowadzą go do podziemnej szkoły, gdzie przy zegarze Plutona słucha Demona uczącego pod postacią małpy. Gdy wybija godzina, instrumenty muzyczne zachęcają Francuzów do skoków. Kiedy wraca z podziemnej szkoły, książę otrzymuje wiadomość o śmierci ojca i wraca do domu. Wyprawia ojcu pogrzeb, po czym wydaje dla ubogich wystawną ucztę i usługuje im przy stole. Pod wpływem bogactw popada w zbytek, sprowadza wino z Węgier, następnie naradza się z przyjaciółmi nad dalszym życiem. Podczas pijatyki książę zapada w sen, a przyjaciele odchodzą. Anioł Stróż budzi księcia i upomina go, książę opiera się za namową Zbytku, Anioł opuszcza księcia, obiecując mu smutny koniec. By uspokoić wzburzone myśli, książę udaje się do ogrodu na spacer i nakazuje bieg kopijny do pierścienia. Po spacerze odpoczywa, a we śnie nękają go piekielne monstra i złowieszcze ognie. By poprawić sobie nastrój i oddalić złowrogie znaki, nakazuje kawalerii rycerski skok. Księciu ukazuje się zmarły ojciec. Dworzanie 


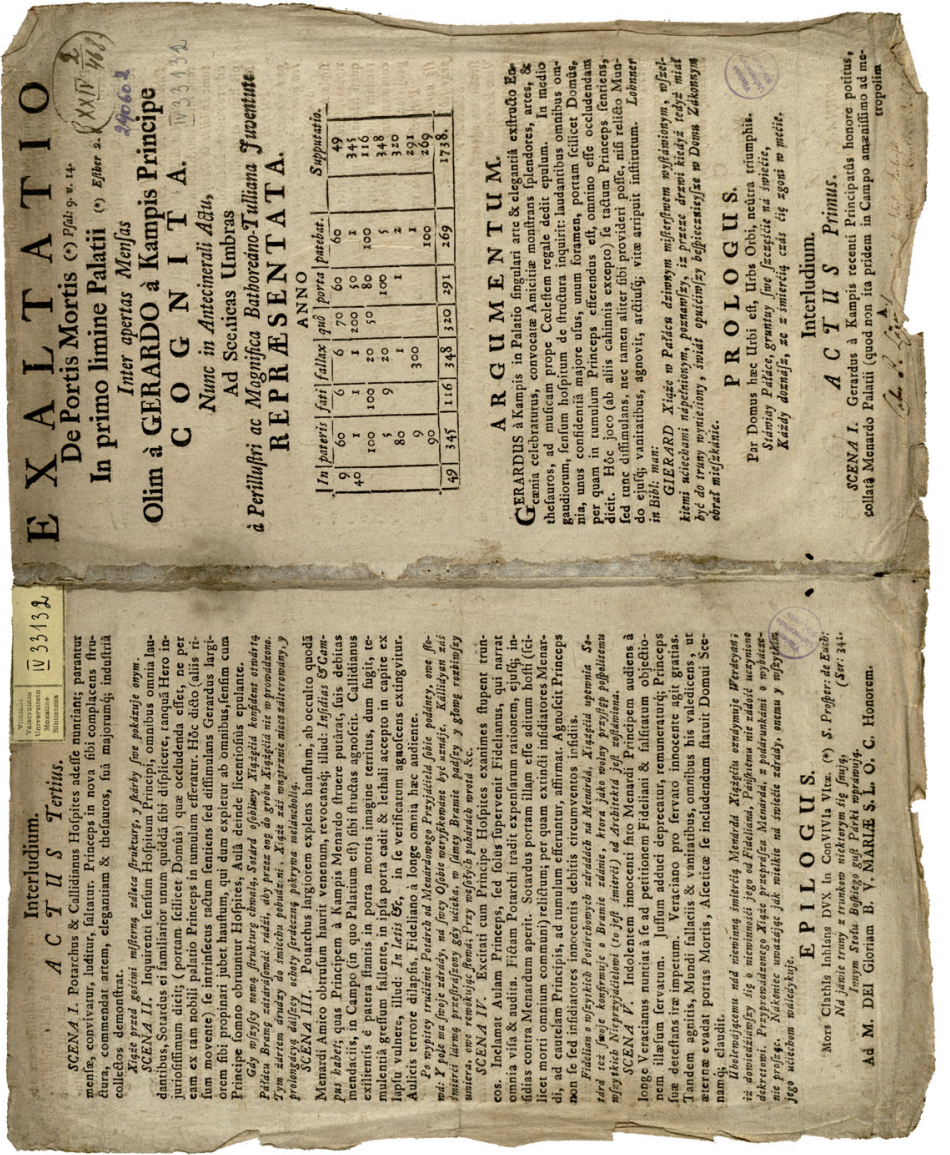

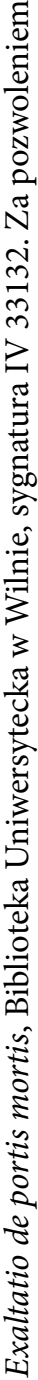


i kawaleria uciekają ze strachu, książę wpada w desperację, niepokoi go głos sumienia. Pojawia się Zbytek, „dla rozerwania melancholii Fortunny skok wyprowadza”. Książę tańczy ze Zbytkiem, do tańca przyłączają się dwie śmierci. Wśród chmur ukazuje się Anioł zemsty, książę przestraszony jego widokiem „pada bez duszy”. Ciało księcia jest wystawione $\mathrm{w}$ trumnie dla żałobników, nagle $\mathrm{z}$ trumny bucha płomień i ciało znika. Anioł ku przestrodze pokazuje księcia w piekle zniewolonego przez Zbytek. - Chór [1]: uczy, że zdeprawowani towarzysze mogą zepsuć nawet najzacniejszych. Chór [2]: nakłania młodzież do umiłowania cnoty. Chór [3]: uczy, że „zbytki smutkiem się kończą".

Treść Prologu, intermediów i epilogu niepodana.

Egzemplarze: Biblioteka Uniwersytecka w Wilnie, IV 32050. Na

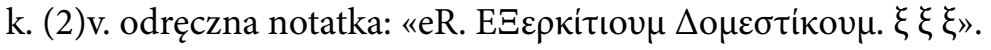

9.

[P. Langanik?]: Exaltatio de portis mortis, inter apertas mensas olim a Gerardo a Kampis Principe cognita, nunc a Bathoreano-Tulliana Iuventute repraesentata anno 1738. [br. m. dr., Wilno?, 1738]. $2^{\circ}$. K. nlb. 2, sygn. $A_{2}$.

[Tytuł nagłówkowy]: EXALTATIO De Portis Mortis * [odsyłacz]: $\left(^{*}\right)$ Psal. 9. v. 14. In primo limine Palatii ${ }^{\star}$ [odsyłacz]: $\left(^{\star}\right)$ Esther. 2. Inter apertas Mensas Olim a GERARDO a Kampis Principe COGNITA. Nunc in Antecinerali Actu, Ad Scenicas Umbras a Perillustri ac Magnifica Bathoreano-Tulliana Juventute REPRAESENTATA. ANNO [1738].

Niżej: tabelka z kolumnami wydzielonymi według słów sentencji «In pateris fati fallax quo porta patebat». «Supputatio». Do przedstawienia roku wystawienia zastosowano liczbowy system używający łacińskiego alfabetu, w którym każdej literze przypisano jedną wartość, rozpoczynając od „a" = 1 itd., „k” = 10 itd., „t” = 100 .

Poniżej: «Argumentum». K. A r. $-\mathrm{A}_{2}$ v.: tekst.

Język: łaciński i polski. 
Gatunek: dramat.

Podzial: Prologus. Interludium. Actus I sc. 1-6. Chorus I. Interludium. Actus II sc. 1-6. Chorus II. Interludium. Actus III sc. 1-5. Epilogus.

Actus III sc. 1: tańce i zabawa («saltatur, luditur»).

Osoby (brak spisu): Gerardus a Kampis; Menardus; Nemesianus, Sotardus, Duces; Lucianus Gotardus, Flavianus, Primores Nobilitatis; Callidianus; Potarchus; Erebianus Magus; mendicus; Veracianus; Archimagirus; Ephaebus; Julianus; Architectus; Fidelianus, Menardi intimus; Conradus; Antonianus; Octavianus; Aulici; Hospites.

Inscenizacja: Actus I sc. 2: Gerardus przyjmuje w gościnie szlachtę z sąsiedztwa; sc. 3: Potarchus u Maga Erebianusa; sc. 4: Potarchus przekupuje żebraka; sc. 5: Potarchus spiskuje z Callidianusem; sc. 6: spotkanie Menardusa z księciem. Actus II sc. 1: Callidianus oskarża Menardusa o zdradę, książę rozkazuje go uwięzić; sc. 2: Fidelianus przejmuje od żebraka fałszywe rejestry wydatków; sc. 3: Veracianus pyta Fidelianusa czytającego list o powód uwięzienia Menardusa; sc. 4: książę budzi się i opowiada dworzanom swój sen; sc. 5: książę wydaje rozkaz zabicia Menardusa i udaje się na bankiet; sc. 6: Fidelianus przekonuje Veracianusa o niewinności Menardusa. Actus III sc. 1: bankiet; sc. 3: Potarchus wypija truciznę; Callidianus ucieka, potyka się i umiera; sc. 5: książę obdarowuje ocalałego Menardusa darami.

Źródło: Lohner in «Bibl: man»: Tobias Lohner, Instructissima bibliotheca manualis concionatoria.

Treść: Gerardus a Kampis, niedawno obdarzony godnością księcia, poleca Menardusowi sporządzić rejestr wydatków na zbudowany pałac. Przyjmuje przybyłych z sąsiedztwa gości, Nemesianusa, Sotardusa, Lucianusa Gotardusa i Flavianusa, którzy winszują mu z okazji otrzymania nowej godności. Książę zaprasza ich na bankiet, tymczasem posyła Callidianusa do Menardusa z poleceniem ukończenia budowy pałacu. Potarchus urażony obdarzeniem Menardusa 
nowym zaszczytem postanawia uknuć spisek na jego zgubę i udaje się do maga Erebianusa, od którego otrzymuje odpowiedź w formie cytatu z Marcjalisa: „I pole też swoje ma zdrady”. Spotyka żebraka, od którego dowiaduje się, że główny architekt spadł z dachu pałacu, następnie posyła na dwór fałszywy rejestr wydatków, według którego Menardus przywłaszczył sobie pensję głównego architekta. Później spotyka Callidianusa, który mu mówi, że Menardusa oskarżono o zamach na życie księcia. Wiedział on bowiem, że architekt przy budowie pałacu zostawił dla nieprzyjaciół księcia wejście, a jednak nie zatrzymał architekta i pozwolił mu uciec. Potarchus przedstawia Callidianusowi swoją intrygę i spiskują razem przeciw Menardusowi. Ten udaje się do księcia $\mathrm{z}$ rejestrem wydatków, Veracianus słucha kalkulacji i kiedy wszystko okazuje się w porządku, poleca przyśpieszyć wykończenie pałacu i przygotowanie bankietu z kuchmistrzem. Callidianus rzuca przed księciem fałszywe oskarżenia na Menardusa. Gerardus poleca Veracianusowi wziąć rejestr od Menardusa i uwięzić go; sam udaje się na spoczynek. Fidelianus, zaufany Menardusa, usłyszawszy o intrygach Potarchusa, gdy spotyka żebraka idącego na dwór z fałszywym rejestrem, ukradkiem zabiera pismo i zabrania żebrakowi wstępu na dwór ze względu na sen księcia. Veracianus spotyka Fidelianusa, dowiaduje się o przyczynie uwięzienia Menardusa i na podstawie pisma, które niósł żebrak, uzmysławia sobie podstęp Callidianusa. Zbudzony ze snu książę wzywa dworzan przestraszony nocnym widzeniem, ręką piszącą na fasadzie pałacu słowa „I pole też swoje ma zdrady” oraz „Przy wesołych pucharach wrota do śmierci otwarte". Przypominając sobie oskarżenia Callidianusa, nakazuje Veracianusowi zabić Menardusa i udaje się na bankiet. Potarchus i Callidianus cieszą się z powodzenia podstępu. Fidelianus przekonuje Veracianusa, by wstrzymał wykonanie wyroku na Menardusie, i obiecuje udowodnić jego niewinność po bankiecie księcia. Veracianus przystaje na to i udaje się do więzienia pocieszyć Menardusa. Przybywają goście, stoły są zastawiane, rozpoczyna się bankiet, zabawa, tańce. Książę pokazuje skarby zgromadzone przez siebie i swoich przodków. Sotardus mówi, że brama pałacu powinna być zamknięta, by nie wyniesiono przez nią księcia do grobowca. Wszyscy śmieją 
się z żartu, książę czuje się urażony, ale ukrywa to. Pod wpływem wypitych trunków Gerardus i goście zapadają w sen. Potarchus wypija truciznę przygotowaną przez przyjaciela Menardusa. Przestraszony marą śmierci Callidianus ucieka, w biegu potyka się, upada w bramie, rozbija głowę i umiera. Przerażony dwór ucieka. Książę z gośćmi budzą się ze snu i widzą trupy, Fidelianus opowiada, co się wydarzyło. Przedstawia też fałszywy rejestr Potarchusa i opisuje jego intrygę. Kiedy książę ubolewa nad śmiercią Menardusa, Veracianus oznajmia, że dzięki interwencji Fidelianusa oszczędził Menardusa. Książę wyrzuca sobie nagły poryw gniewu, prosi Menardusa o wybaczenie i wręcza mu dary. Wreszcie, poznawszy zdrady i marność świata, porzuca wszystko, by uniknąć bram wiecznej śmierci, i postanawia zamknąć się w domu ascezy. - Prolog, chóry i epilog są jednowersowymi sentencjami łacińskimi, oddanymi w języku polskim przez rymowany dystych, treściowo związanymi $z$ tematem dramatu, o charakterze filozoficznym i egzystencjalnym. Chór I zawiera cytat z tragedii Seneki; chór II z Listu do Hebrajczyków 13, 14; epilog z pism św. Prospera.

Treść interludiów niepodana.

Egzemplarze: Biblioteka Uniwersytecka w Wilnie, IV 33132. Prow. na k. A r.: «Labor P. Langanik».

Uwaga: rękopiśmienna notatka na k. A $A_{1}$.: «R. M. Josepho Jankowski offert Laur. [...] S. JESU»; dramat zapustny, jak wskazuje tytuł; w Epilogu chronostych przedstawiający rok wystawienia. 


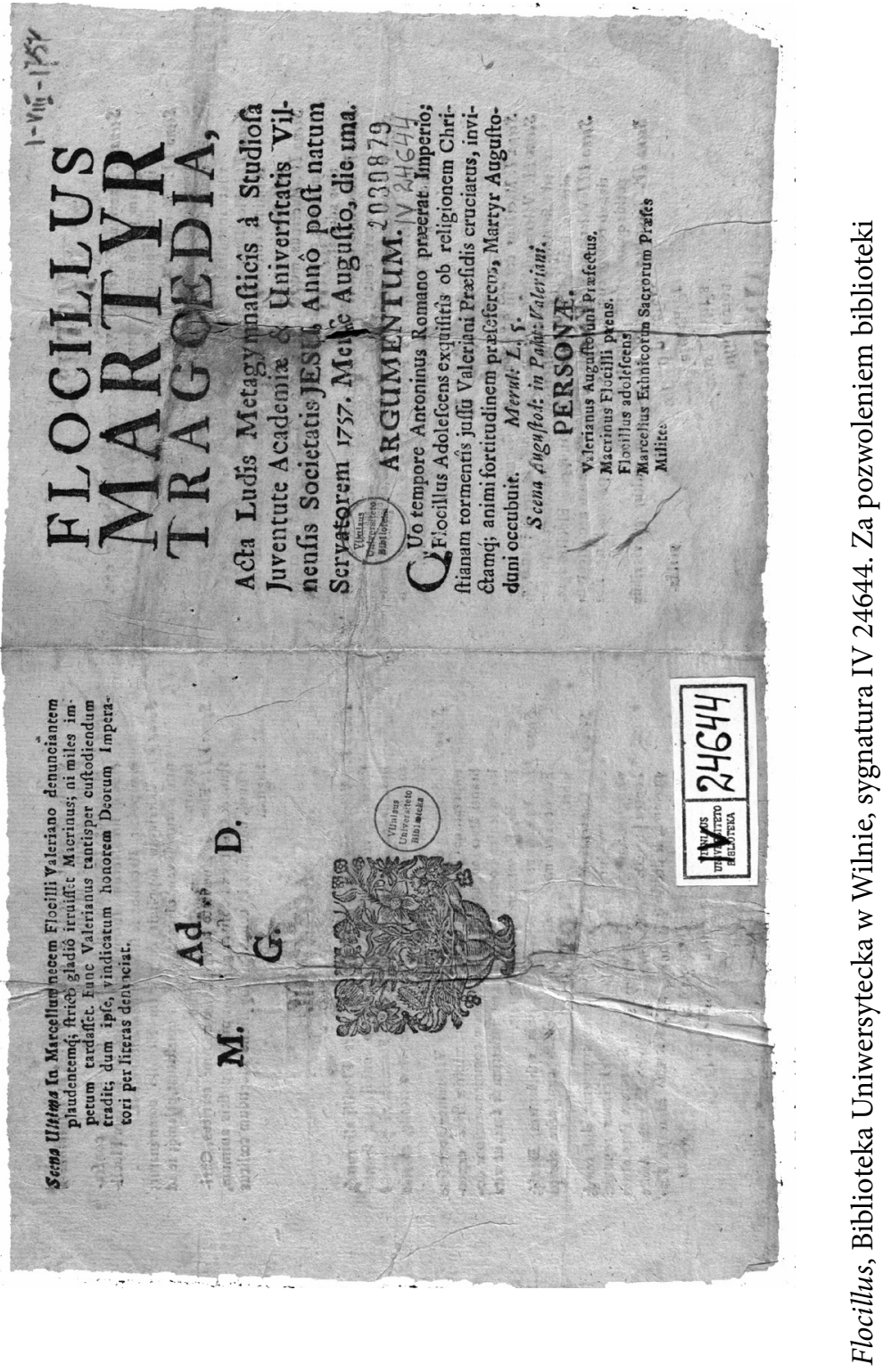


10.

Flocillus martyr tragoedia, a iuventute Academiae Vilnensis S.I. anno 1757 mense Augusto, die prima. [br. m. dr., Wilno?, Druk Akad. S.I.?, przed 1 VIII 1757]. $4^{\circ}$.

K. nlb. i nsygn. 2, $\left[\mathrm{a}_{2}\right]$.

[Tytuł nagłówkowy]: FLOCILLUS MARTYR TRAGOEDIA, Acta Ludis Metagymnasticis a Studiosa Juventute Academiae \& Universitatis Vilnensis Societatis JESU, Anno post natum Servatorem 1757. Mense Augusto, die Ima.

Niżej: «Argumentum», «Personae». K. $\left[a_{1}\right]$ v. $-\left[a_{2}\right]$ v.: tekst.

Język: łaciński.

Gatunek: tragedia.

Podział: Actus I sc. 1-6. Actus II sc. 1-7. Actus III sc. 1-4, scena ultima.

Osoby: Valerianus Augustoduni Praefectus; Macrinus Flocilli parens; Flocillus adolescens; Marcellus Ethnicorum Sacrorum Praeses; Milites.

Miejsce akcji: Augustoduni in Palatio Valeriani.

Inscenizacja: Actus I sc. 2: Marcellus skarży się przed Valerianusem; sc. 3: uwięzienie Flocillusa; sc. 4: Macrinus wyjednuje odroczenie wyroku. Actus II sc. 3: Valerianus mówi Flocillusowi o wyroku śmierci dla ojca. Actus III sc. 1: rozmowa Valerianusa z Marcellusem; sc. 3: Valerianus rozkazuje zabrać Flocillusa; sc. ultima: Macrinus napada $\mathrm{z}$ mieczem na Marcellusa.

Źródło: Merul. 1. 5.

Treść: Macrinus poleca Flocillusa Valerianusowi, by z jego pomocą młodzieniec został przyjęty do efebów Antonina. Marcellus skarży się Valerianusowi, że Flocillus strącił $\mathrm{z}$ ołtarza wizerunek Jowisza i podeptał go. Flocillus wyznaje, że gardzi bogami i czci Chrystusa, za co Valerianus rozkazuje wtrącić go do więzienia. Macrinus wy- 
jednuje od Valerianusa odroczenie kary śmierci dla syna, pod warunkiem że Flocillus wyrzeknie się Chrystusa i zacznie czcić bożki. Macrinus, bezskutecznie próbując odwieść syna od prawdziwej wiary, przekonuje go, że jeśli Flocillus nie zacznie czcić bogów, on zostanie skazany na śmierć. Przedstawia również swój plan Valerianusowi. Tymczasem Valerianus, często nakłaniany przez Marcellusa do prześladowania chrześcijan, rozważa, co uczynić z Flocillusem. Kiedy informuje go o wyroku śmierci na ojcu, młodzieniec prosi go, żeby zamiast ojca sam mógł się poddać wyrokowi. Macrinus, udając smutek, gani syna, że z jego powodu poniesie karę śmierci. Kiedy Marcellus, chcąc uspokoić pospólstwo wzburzone z powodu zniszczenia posągu Jowisza, żąda dla Flocillusa kary śmierci, Macrinus pragnie umrzeć razem $\mathrm{z}$ synem. Valerianus grozi Flocillusowi śmiercią, jeśli ten nie przebłaga Jowisza i nie oświadczy publicznie, że to uczyni. Flocillus, nie bojąc się tortur, prosi Chrystusa i mieszkańców nieba o siłę wytrwania w pobożnych postanowieniach i siłę fizyczną do zniesienia męki. Marcellus w rozmowie z Valerianusem o niezwykłej wytrwałości Flocillusa i innych chrześcijan w czasie prześladowań domaga się zasądzenia wyroku śmierci na młodzieńcu, jeśli ten się nie ugnie. Macrinus wyrzuca Flocillusowi jego postępowanie, Flocillus stara się złagodzić ból ojca, oświadcza zarazem, że nie dopuści, by ojciec oddał życie zamiast niego. Młodzieniec na rozkaz Valerianusa zostaje zabrany. Kiedy Macrinus pyta o los Flocillusa, Valerianus odpowiada, że nie powinien opłakiwać syna, który gardzi ojczystymi świętościami i bogami. Flocillus został oddany kapłanowi Marcellusowi. Gdy kapłan informuje Valerianusa o śmierci Flocillusa, Macrinus rzuca się na niego z mieczem, ale żołnierz go powstrzymuje. Valerianus rozkazuje uwięzić go do czasu, aż pisemnie nie powiadomi cesarza, że zadośćuczyniono czci bogów.

Egzemplarze: Biblioteka Uniwersytecka w Wilnie, IV 24644.

Uwaga: por. DS II 1, nr 338, tragedia o podobnej treści, tutaj św. Flocellus. 


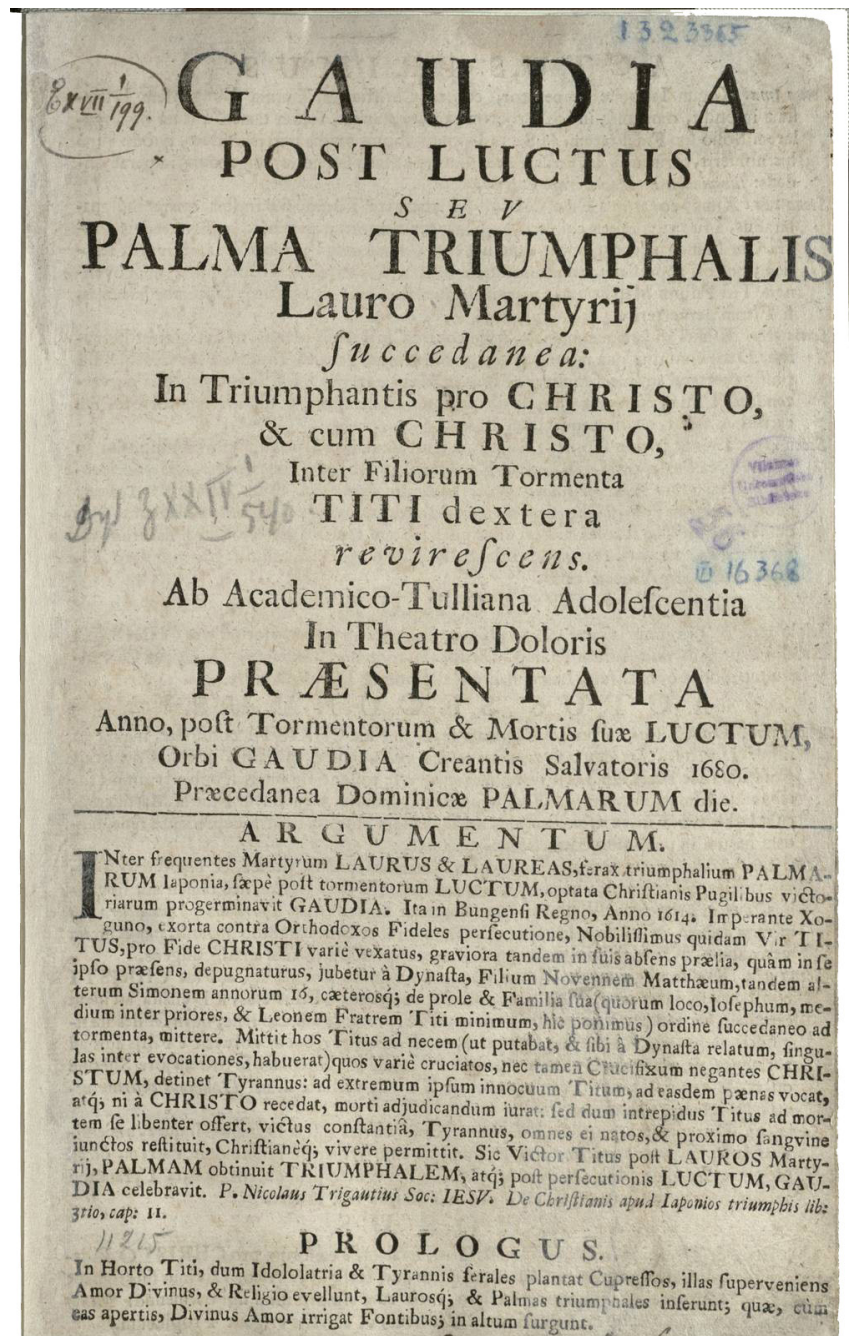

Gaudia post luctus, Biblioteka Uniwersytecka w Wilnie, sygnatura III 16368. Dostępne w bibliotece cyfrowej www.epaveldas.lt: http://www.epaveldas.lt/ object/recordDescription/VUB/VUB01-000548605 (dostęp: 22.09.2017) 


\section{1.}

Gaudia post luctus seu palma triumphalis in Titi dextera revirescens, ab Academico-Tulliana Adolescentia in theatro doloris praesentata anno 1680, praecedanea Dominicae Palmarum die [br. m. dr., Wilno?, Druk Akad. S.I.?, przed 13 IV 1680]. $2^{\circ}$.

K. nlb. i nsygn. 2, $\left[\mathrm{a}_{2}\right]^{28}$.

[Tytuł nagłówkowy]: GAUDIA POST LUCTUS SEV PALMA TRIUMPHALIS Lauro Martyrij succedanea: In Triumphantis pro CHRISTO, \& cum CHRISTO, Inter Filiorum Tormenta TITI dextera revirescens. Ab Academico-Tulliana Adolescentia In Theatro Doloris PRAESENTATA Anno, post Tormentorum \& Mortis suae LUCTUM, Orbi GAUDIA Creantis Salvatoris 1680. Praecedanea Dominicae PALMARUM die [13 IV 1680].

Niżej: «Argumentum». K. [ $\left.\mathrm{a}_{1}\right] \mathrm{r} .-\left[\mathrm{a}_{2}\right]$ v.: tekst.

Język: łaciński.

Gatunek: tragedia.

Podział: Prologus. Actus I sc. 1-4. Chorus. Actus II sc. 1-4. Chorus. Actus III sc. 1-4. Chorus. Actus IV sc. 1-4. Chorus. Actus V sc. 1-4. Epilogus.

Chorus [1]: „lessus feralis”, „salientes calvariae”, „laetus concentus”. Chorus [2]: Religio i Amor Divinus śpiewają „Ty, o Jezu, jesteś moją radością”. Chorus [3]: śpiew „Ogromnie się weselę”. Actus IV sc. 2: „caelestis cantus et musica”, „laetus concentus”. Epilogus: Genii Titi, Leonis, Simonis, Iosephi, Matthaei, Xuni occinentes: „Quis nos separabit a Charitate Christi”.

Osoby (brak spisu): Idololatria; Tyrannis; Amor Divinus; Religio; Xogun, Iaponiae Imperator; Ximus, Bungensis Dynasta; Titus; Kimus, tormentorum praefectus; Matthaeus, Iosephus, Simon, Titi filii; Titi Familia; Ioquez, Dynastae Filius; Leon, Titi Frater; Xunus, Cae-

28 Z uwagi na ucięte $\mathrm{z}$ dołu karty trudno stwierdzić, czy były one sygnowane. 
sareus Filius; Genius Titi; Genius Leonis; Genius Simonis; Genius Iosephi; Genius Matthaei; Genius Xuni; Kassoius; Orator.

Inscenizacja: Prologus: Idololatria i Tyrannis sadzą w ogrodzie cyprysy, Amor Divinus i Religio wyrywają je i sadzą laury i palmy zwycięstwa. Actus I sc. 2: Ximus daje Kimusowi magiczny pierścień; sc. 3: Kimus zasięga rady bogów; sc. 4: Kimus przechodzi przez miejsce kaźni, przemawiają głowy zabitych chrześcijan. Chorus [1]: tańczące czaszki. Actus II sc. 1: Kimus zabiera Matthaeusa na tortury; sc. 2: tortury Matthaeusa; sc. 3: Iosephus idzie na męki; sc. 4: Kimus i Iosephus spotykają Ioqueza. Chorus [2]: posąg z czaszek i kości, pomnik zwycięstwa z krzyży i szafotów. Actus III sc. 1: tortury Iosephusa; sc. 2: Kimus zabiera na tortury Simona i Leona; sc. 4: Simon i Leon wzajemnie się torturują; rzuceni na pożarcie dzikim zwierzętom. Chorus [3]: uskrzydlone Geniusze Leona, Simona, Iosephusa, Matthaeusa i Xunusa lecą do krzyża. Actus IV sc. 1: Xunus wpada w obłęd; sc. 2: śpiew i muzyka w więzieniu; sc. 4: Ximus udaje się do cesarza. Chorus [4]: Religio, Amor Divinus, Idololatria i Tyrannis łowią ryby, Idololatria i Tyrannis toną. Actus V sc. 2: Kimus staje przed Ximusem. Epilogus: Orator zamyka scenę.

Źródło: Nicolaus Trigautius, De Christianis apud Iaponios triumphis, lib. 3, cap. 11.

Treść: Prologus: Idololatria i Tyrannis sadzą w ogrodzie Titusa cyprysy, nadchodzą Amor Divinus i Religio, wyrywają je i zasadzają wawrzyny oraz triumfalne palmy, które rosną podlewane przez Divinus Amor. - Xogun, cesarz Japonii, podburza przeciw chrześcijanom dynastę Ximusa $\mathrm{z}$ Bungum, Titusa jednak, $\mathrm{z}$ uwagi na jego niezwykłą lojalność, rozkazuje nawrócić na religijne obrzędy Japonii dobrym sposobem oraz przez lekkie tortury i męki jego synów. Ximus na próżno usiłuje odwieść Titusa od wiary w Chrystusa. Daje Kimusowi w prezencie pierścień z magicznym kamieniem i poleca wydać na męki Matthaeusa, obiecując zarazem najwyższe zaszczyty. Kimus pyta bogów, jakim sposobem albo rodzajem tortur mógłby odwieść Tytusa od wiary w Chrystusa. Słyszy odpowiedź: „upieczo- 
ny chłopiec katem". Przechodząc przez miejsce kaźni, gdzie zgodnie z japońskim zwyczajem ułożone są w rzędzie głowy zabitych chrześcijan, słyszy ich słowa: „Tutaj są palone ofiary miłe Polusowi. Ale stąd Kimus da ofiarę Styksowi", które interpretuje na swoją korzyść, a dla Titusa wznosi wysoki krzyż. Kiedy Titus umacnia całą swą rodzinę w wierze w Chrystusa, nadchodzi Kimus i zabiera na męki do dynasty jego syna Matthaeusa. Młodzieniec z pogodą znosi tortury. Tyran rozkazuje go zamknąć w więzieniu i żąda od Titusa wydania na męki następnego syna, kłamiąc, że Matthaeus już nie żyje. Zgnębiony Titus błaga, więc Kimus pozwala mu wybrać, którego ze swych synów pośle na męki i śmierć, ale młodszy Iosephus ofiaruje się zamiast starszego Simona i szlachetnie idzie na tortury. Kimus i Iosephus w drodze do dynasty spotykają Ioqueza, bliskiego przyjaciela Iosephusa, który błaga Kimusa, by go nie zabierał na męki. Kiedy nie uzyskuje nic swoimi błaganiami, poczytuje to sobie za wzgardę i postanawia pozbawić Kimusa łaski ojca, a nawet życia. Iosephus pozostaje nieugięty w obliczu tortur, co staje się źródłem udręki Kimusa i w ten sposób wypełnia się przepowiednia „upieczony chłopiec katem". Dynasta rozkazuje zabrać pozostałych synów Titusa i jego brata na męki. Kimus zakuwa w kajdany Simona oraz Leona, brata Titusa, i proponuje, by młodzieńcy sami sobie zadawali męki. W obecności Xunusa i Ioqueza, syna dynasty, Leon i Simon torturują się nawzajem płonącym węglem i rozpuszczonym woskiem. Kiedy tortury nie odnoszą skutku, Kimus rozkazuje rzucić ich na pożarcie dzikim zwierzętom, ale te łagodnieją na znak krzyża zrobionego przez młodzieńców. Kimus, przypisując to czarom, rozkazuje wtrącić młodzieńców do więzienia. Przez moc magicznego pierścienia oraz słowa Ioqueza Xunus przeciwstawia się Kimusowi. Ten przykłada księciu do ust pierścień, przez co Xunus popada w szaleństwo i dołącza w więzieniu do młodzieńców, których pociesza niebiański śpiew i muzyka. Boska moc uwalnia od szaleństwa księcia, który przyjmuje wiarę w Chrystusa i chce za niego umrzeć. Ximus dowiaduje się o obłędzie Xunusa spowodowanym przez Kimusa i udaje się do cesarza. Oświadcza, że nie osiągnął niczego z Titusem i jego synami, a nawet sam Xunus wpadł w obłęd przez magiczne sztuczki 
Kimusa. Cesarz rozkazuje jeszcze raz wystawić Titusa i młodzieńców na próbę, by uwolnić od śmierci swojego syna. Następnie poleca pozwolić Titusowi żyć po chrześcijańsku, zwrócić mu brata i synów, a Kimusa skazać na śmierć. Kimus zostaje uznany za głównego wroga cesarza i ma zostać zawieszony na wysokim krzyżu, kiedyś wzniesionym przez niego dla Titusa. Ximus bezskutecznie próbuje nawrócić Titusa i jego synów, w końcu pozwala im na chrześcijańskie życie. Titus i jego synowie cieszą się, że przez tortury pokazali Niebu miłą ofiarę. - Epilogus: Geniusze Titusa, Leona, Simona, Iosephusa, Matthaeusa i Xunusa śpiewają „Któż nas oddzieli od miłości do Chrystusa" i głoszą, że świat w męce Chrystusa ma perspektywę prawdziwej radości po smutku. Mówca, chwaląc to, zamyka scenę. Chorus [1]: Idololatria i Tyrannis na instrumencie sporządzonym z kości i czaszek wiernych, którzy zginęli za Chrystusa, zamierzają zaintonować lament pogrzebowy dla chrześcijan. Grają wesołą melodię dla podrygujących czaszek. Religio i Divinus Amor triumfują. Chorus [2]: Idololatria i Tyrannis na progu domu Titusa stawiają posąg z czaszek i kości wiernych zmarłych za Chrystusa. Kiedy Religio i Amor Divinus naznaczają go swoimi krzyżami, upada i rozsypuje się na kawałki. Religio i Amor, śpiewając „Ty, o Jezu, jesteś moją radością”, wznoszą trofeum z krzyży i szafotów. Chorus [3]: Amor Divinus wyrywa z płomieni świata Geniusze Leona, Simona, Matthaeusa, Iosephusa i Xunusa, dodaje im skrzydeł i rozpala ich własnym płomieniem. Te ze śpiewem „Ogromnie się weselę" lecą do krzyża, paląc się w ofierze dla najwyższego bóstwa. Chorus [4]: Na bezkresnym Oceanie Świata Religio i Amor Divinus, a z drugiej strony Idololatria i Tyrannis łowią ryby. Religio i Amor Divinus zgodnie ze słowami Chrystusa "Odtąd ludzi będziesz łowił” łapią w swe sieci Geniusze Titusa, Leona, Simona, Matthaeusa, Iosephusa i Xunusa; Idololatria i Tyrannis $\mathrm{z}$ wściekłości rozhuśtują swą łódkę, w rezultacie toną.

Egzemplarze: Biblioteka Uniwersytecka w Wilnie, III 16368: egzemplarz przycięty z dołu, na k. $\left[\mathrm{a}_{1}\right] \mathrm{r}$. widać odręczną notatkę, być może nazwisko autora. 


\section{Bibliografia}

Dramat staropolski od poczatków do powstania sceny narodowej. Bibliografia, t. 2: Programy drukiem wydane do r. 1765, cz. 1: Programy teatru jezuickiego, oprac. W. Korotaj, J. Szwedowska, M. Szymańska, Wrocław 1976.

Kadulska I., Teatr jezuicki XVIII i XIX wieku w Polsce. Z antologia dramatu, Gdańsk 1997.

Korotaj W., Z problematyki staropolskich programów teatralnych, w: Wrocławskie spotkanie teatralne, red. W. Roszkowska, Wrocław 1967.

Niedźwiedź J., Kultura literacka Wilna (1323-1655). Retoryczna organizacja miasta, Kraków 2012.

Okoń J., Dramat i teatr szkolny. Sceny jezuickie XVII wieku, Wrocław 1970.

Piechnik L., Dzieje Akademii Wileńskiej, t. 1-4, Rzym 1983-1990.

Poplatek J., Studia z dziejów jezuickiego teatru szkolnego w Polsce, Wrocław 1957.

Ratio atque institutio studiorum czyli ustawa szkolna Towarzystwa Jezusowego, wstęp i oprac. K. Bartnicka, T. Bieńkowski, Warszawa 2000.

Rezanov V.I., Iz istorii russkoj dramy. Škol'nye dejstva XVII-XVIII vv. i teatr iezuitov, Moskva 1910 (В.И. Резанов, Из истории русской драмыь. Школьные действа XVII-XVIII вв. и театр иезуитов, Москва 1910).

Rezanov V.I., K istorii russkoj dramy. Ėkskurs v oblast' teatra iezuitov, Nežin 1910 (В.И. Резанов, К истории русской драмьь. Экскурс в область театра иезуитов, Nežin 1910).

Rezanov V.I., Škol’nye dramy pol'sko-litovskih iezuitskih kollegij, Nežin 1916 (В.И. Резанов, Школьные драмы польско-литовских иезуитских коллегий, Nežin 1916).

Roszkowska W., Uwagi o programowości teatru barokowego w Polsce, w: Wrocławskie spotkanie teatralne, red. W. Roszkowska, Wrocław 1967.

Simon L., Dykcjonarz teatrów polskich czynnych od czasów najdawniejszych do roku 1863, Warszawa 1935.

Sommervogel C., de Backer A., de Backer A., Carayon A., Bibliothèque de la Compagnie de Jésus, t. 1-12, Bruxelles-Paris 1890-1960.

Ulčinaitė E., Lietuvos jèzuitu teatras. XVI-XVIII amžiaus dramu rinktiné, Vilnius 2008.

Zaborskaitė V., Prie Lietuvos teatro ištakų. XVI-XVIII a. mokyklinis teatras, Vilnius 1981.

Załęski S., Jezuici w Polsce, t. 1-5, Lwów-Kraków 1901-1906. 